\title{
Assessment of long-term WRF-CMAQ simulations for understanding direct aerosol effects on radiation "brightening" in the United States
}

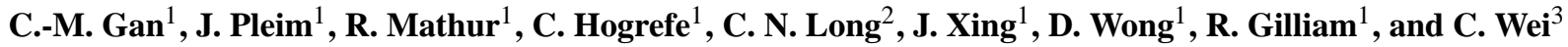 \\ ${ }^{1}$ Atmospheric Modeling and Analysis Division, National Exposure Research Laboratory, \\ US Environmental Protection Agency, Research Triangle Park, North Carolina, USA \\ ${ }^{2}$ Cooperative Institute for Research in Environmental Sciences (CIRES), \\ University of Colorado Boulder and NOAA, Boulder, Colorado, USA \\ ${ }^{3}$ Max Planck Institute for Chemistry, Mainz, Germany
}

Correspondence to: C.-M. Gan (chuenmeei@gmail.com, gan.meei@epa.gov)

Received: 18 May 2015 - Published in Atmos. Chem. Phys. Discuss.: 1 July 2015

Revised: 20 October 2015 - Accepted: 23 October 2015 - Published: 3 November 2015

\begin{abstract}
Long-term simulations with the coupled WRFCMAQ (Weather Research and Forecasting-Community Multi-scale Air Quality) model have been conducted to systematically investigate the changes in anthropogenic emissions of $\mathrm{SO}_{2}$ and $\mathrm{NO}_{x}$ over the past 16 years (1995-2010) across the United States (US), their impacts on anthropogenic aerosol loading over North America, and subsequent impacts on regional radiation budgets. In particular, this study attempts to determine the consequences of the changes in tropospheric aerosol burden arising from substantial reductions in emissions of $\mathrm{SO}_{2}$ and $\mathrm{NO}_{x}$ associated with control measures under the Clean Air Act (CAA) especially on trends in solar radiation. Extensive analyses conducted by Gan et al. (2014a) utilizing observations (e.g., SURFRAD, CASTNET, IMPROVE, and ARM) over the past 16 years (1995-2010) indicate a shortwave (SW) radiation (both allsky and clear-sky) "brightening" in the US. The relationship of the radiation brightening trend with decreases in the aerosol burden is less apparent in the western US. One of the main reasons for this is that the emission controls under the CAA were aimed primarily at reducing pollutants in areas violating national air quality standards, most of which were located in the eastern US, while the relatively less populated areas in the western US were less polluted at the beginning of this study period. Comparisons of model results with observations of aerosol optical depth (AOD), aerosol concentration, and radiation demonstrate that the coupled WRFCMAQ model is capable of replicating the trends well even
\end{abstract}

though it tends to underestimate the AOD. In particular, the sulfate concentration predictions were well matched with the observations. The discrepancies found in the clear-sky diffuse SW radiation are likely due to several factors such as the potential increase of ice particles associated with increasing air traffic, the definition of "clear-sky" in the radiation retrieval methodology, and aerosol semi-direct and/or indirect effects which cannot be readily isolated from the observed data.

\section{Introduction}

Sulfate and nitrate are important secondary aerosols as they are key contributors to the airborne $\mathrm{PM}_{2.5}$ (particulate matter that is $2.5 \mu \mathrm{m}$ in diameter and smaller) mass in the United States (US) (Hand et al., 2012, 2013; Blanchard et al., 2013). Because of its adverse impact on human health and ecosystems, surface-level $\mathrm{PM}_{2.5}$ is extensively monitored to determine compliance with the particulate matter National Ambient Air Quality Standards (NAAQS). Moreover, knowledge of the alteration in the net radiative flux associated with the change of anthropogenic aerosol concentrations is essential to better understand aerosol radiative forcing and its effect on Earth's radiation budget (Chin et al., 2014; IPCC, 2014a, b). For example, radiation brightening is the gradual increase in the amount of shortwave irradiance at Earth's surface which has been affected by changes in atmospheric constituents 
such as anthropogenic aerosol and cloudiness. In a recent study, Gan et al. (2014a) showed the effects of the implementation of controls under the Clean Air Act (CAA) on changing the anthropogenic aerosols burden and associated radiation brightening in the US. This extensive analysis of various observation networks over the past 16 years (1995-2010) indicated that both all-sky and clear-sky shortwave (SW) radiation have experienced "brightening" in the US, especially in the east region (Wild et al., 2009; Long et al., 2009; Augustine and Dutton, 2013). It however remains challenging to quantify the aerosol SW radiative forcing solely based on measurements since the distribution, lifetime, and sources of anthropogenic aerosol are heterogeneous in space and time. Here we extend our previous analysis (Gan et al., 2014a) by using the two-way coupled Weather Research and Forecasting (WRF)-Community Multi-scale Air Quality (CMAQ) model (Wong et al., 2012) to further investigate the changing aerosol effects on radiation "brightening". This study is also an assessment of the ability of the coupled model to replicate the observed trends of SW radiation, particulate matter and aerosol optical depth utilizing a comprehensive emission data set (Xing et al., 2013).

Section 2 gives a brief overview of each observation network together with their measurements. The configurations of the coupled model together with methodologies that are applied to each data set are also briefly discussed in this section. The results from the analyses of these data sets are presented in Sect. 3. In this section, the effects of the reduction in $\mathrm{SO}_{2}$ and $\mathrm{NO}_{x}$ emissions on the radiation budget are assessed by using observed and modeled AOD (aerosol optical depth) and surface-level particulate matter. In addition, observed and modeled all-sky and clear-sky downwelling SW radiation are compared to further investigate trends in the aerosol-direct effect. In Sect. 4 we summarize the findings and conclusions from our analyses.

\section{Data set}

\subsection{Observations}

The comprehensive observational data analysis presented in a previous study by Gan et al. (2014a) is used in this study. This section provides a brief overview of the observations. The reader is referred to Gan et al. (2014a) for additional details of the observational data analysis. Data from several observational networks including SURFRAD (Surface Radiation Budget Network), Atmospheric Radiation Measurement (ARM), CASTNET (Clean Air Status and Trend Network), and IMPROVE (Interagency Monitoring of Protection Visual Environments) from 1995 to 2010 are used in this study for comparison with model results across the US. The six sites from SURFRAD and one site from ARM, listed in Table 1 and shown in Fig. 1, are the main focus in this study. They are paired with the closest sites from CASTNET and IMPROVE

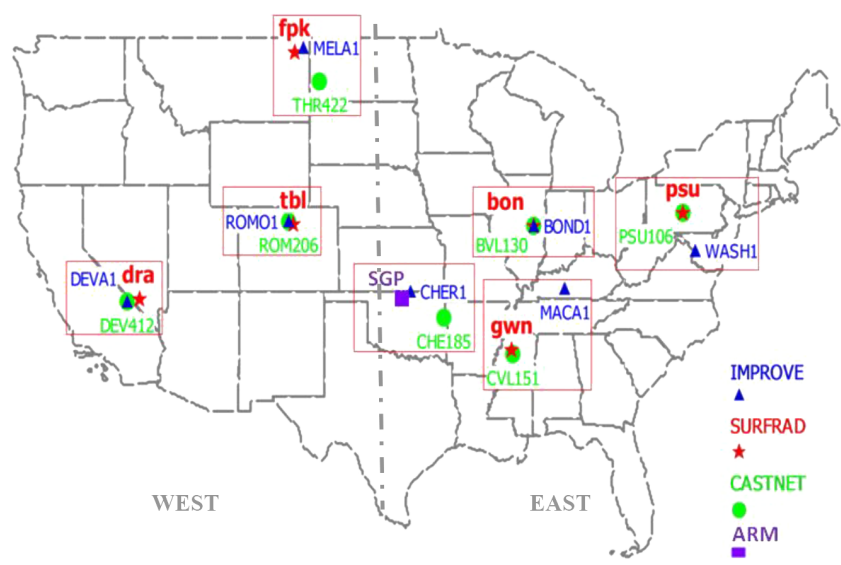

Figure 1. Locations of various sites in the SURFRAD, ARM, CASTNET, and IMPROVE networks. This figure is adapted from Fig. 1 of Gan et al. (2014a).

with the longest available measurements within the simulation period. Note that some sites are farther away from the SURFRAD sites while some are closer (see "Distance" in Table 1 for more information). For example, the Bondville group has all three sites (SURFRAD, CASTNET, and IMPROVE) co-located while the Goodwin Creek group has the IMPROVE site $\sim 500 \mathrm{~km}$ away from the SURFRAD site. Measurements of interests are SW radiation, aerosol composition concentrations near the surface and AOD. In this study, we required data completeness of $80 \%$ or greater for each individual year to minimize any artificial effects on inferred seasonal variations and trends. This criterion was met for each year at all sites for the time periods listed in Table 1. For example, observed AOD is only available after 1997 so the trend comparison spans 1997-2010 instead of 1995-2010. Additional details on the quality of the data and the methodology used to process each data set can be found in Gan et al. (2014a).

\subsection{Weather Research and Forecasting (WRF)-Community Multi-scale Air Quality (CMAQ) model}

The coupled two-way WRF-CMAQ (Wong et al., 2012) model simulations were performed with a configuration based on coupling WRFv3.4 and CMAQv5.0.2. For this study, the output temporal resolution is $1 \mathrm{~h}$ while the modeling domain covering the continental US (CONUS) (see Fig. 1) is discretized with grid cells of $36 \mathrm{~km}$ by $36 \mathrm{~km}$ size in the horizontal and with 35 vertical layers of varying thickness (between the surface and $50 \mathrm{mb}$ ). Two sets of simulations (with aerosol feedback, FB, and without aerosol feedbacks, NFB) are performed from 1990 to 2010 but only results from 1995 to 2010 are analyzed in this study due to the lack of observations for earlier time periods. Note that the aerosol feedback simulation involved only the direct aerosol 
Table 1. Listing of site identification of each site for different networks and their measurement period which are used in this study. Distance means the approximate distance between SURFRAD/ARM sites and CASTNET or IMPROVE sites. This table is adapted from Gan et al. (2014a).

\begin{tabular}{|c|c|c|c|c|c|c|}
\hline SURFRAD/ARM & $\begin{array}{l}\mathrm{SW} \\
\text { radiation }\end{array}$ & AOD & CASTNET & $\begin{array}{l}\text { Aerosol } \\
\text { concentration }\end{array}$ & IMPROVE & $\begin{array}{l}\text { Aerosol } \\
\text { concentration }\end{array}$ \\
\hline $\begin{array}{l}\text { PSU } \\
\text { (Penn State, PA) } \\
\text { Elevation: } 0.38 \mathrm{~km} \\
\text { Lat: } 40.72^{\circ} \\
\text { Long: }-77.93^{\circ}\end{array}$ & 1999-2010 & 1999-2009 & $\begin{array}{l}\text { PSU106 } \\
\text { (Penn State, PA) } \\
\text { Distance: } 0 \mathrm{~km} \\
\text { Elevation: } 0.38 \mathrm{~km} \\
\text { Lat: } 40.72^{\circ} \\
\text { Long: }-77.93^{\circ}\end{array}$ & 1990-2010 & $\begin{array}{l}\text { WASH1 } \\
\text { (Washington, DC) } \\
\text { Distance: } 210 \mathrm{~km} \\
\text { Elevation: } 0.02 \mathrm{~km} \\
\text { Lat: } 38.88^{\circ} \\
\text { Long: }-77.03^{\circ}\end{array}$ & 1990-2010 \\
\hline $\begin{array}{l}\text { BON } \\
\text { (Bondville, IL) } \\
\text { Elevation: } 0.23 \mathrm{~km} \\
\text { Lat: } 40.05^{\circ} \\
\text { Long: }-88.37^{\circ}\end{array}$ & $1995-2010$ & 1997-2010 & $\begin{array}{l}\text { BVL130 } \\
\text { (Bondville, IL) } \\
\text { Distance: } 0 \mathrm{~km} \\
\text { Elevation: } 0.21 \mathrm{~km} \\
\text { Lat: } 40.05^{\circ} \\
\text { Long: }-88.37^{\circ}\end{array}$ & $1990-2010$ & $\begin{array}{l}\text { BONL1 } \\
\text { (Bondville, IL) } \\
\text { Distance: } 0 \mathrm{~km} \\
\text { Elevation: } 0.21 \mathrm{~km} \\
\text { Lat: } 40.05^{\circ} \\
\text { Long: }-88.37^{\circ}\end{array}$ & 2001-2010 \\
\hline $\begin{array}{l}\text { GWN } \\
\text { (Goodwin Creek, MS) } \\
\text { Elevation: } 0.1 \mathrm{~km} \\
\text { Lat: } 34.25^{\circ} \\
\text { Long: }-89.87^{\circ}\end{array}$ & $1995-2010$ & 1997-2010 & $\begin{array}{l}\text { CVL151 } \\
\text { (Coffeeville, MS) } \\
\text { Distance: } 30 \mathrm{~km} \\
\text { Elevation: } 0.1 \mathrm{~km} \\
\text { Lat: } 34.00^{\circ} \\
\text { Long: }-89.80^{\circ}\end{array}$ & $1990-2010$ & $\begin{array}{l}\text { MACA1 } \\
\text { (Mammoth Cave NP, KY) } \\
\text { Distance: } 500 \mathrm{~km} \\
\text { Elevation: } 0.25 \mathrm{~km} \\
\text { Lat: } 37.13^{\circ} \\
\text { Long: }-86.15^{\circ}\end{array}$ & 1992-2010 \\
\hline $\begin{array}{l}\text { SGP } \\
\text { (South Great Plain, OK) } \\
\text { Elevation: } 0.31 \mathrm{~km} \\
\text { Lat: } 36.80^{\circ} \\
\text { Long: }-97.50^{\circ}\end{array}$ & $1997-2010$ & 1996-2007 & $\begin{array}{l}\text { CHE185 } \\
\text { (Cherokee, OK) } \\
\text { Distance: } 270 \mathrm{~km} \\
\text { Elevation: } 0.3 \mathrm{~km} \\
\text { Lat: } 35.75^{\circ} \\
\text { Long: }-94.67^{\circ}\end{array}$ & $2002-2010$ & $\begin{array}{l}\text { CHER1 } \\
\text { (Cherokee Nation, OK) } \\
\text { Distance: } 50 \mathrm{~km} \\
\text { Elevation: } 0.34 \mathrm{~km} \\
\text { Lat: } 36.93^{\circ} \\
\text { Long: }-97.02^{\circ}\end{array}$ & 2003-2010 \\
\hline $\begin{array}{l}\text { FPK } \\
\text { (Fort Peck, MT) } \\
\text { Elevation: } 0.63 \mathrm{~km} \\
\text { Lat: } 48.31^{\circ} \\
\text { Long: }-105.10^{\circ}\end{array}$ & 1996-2010 & 1997-2010 & $\begin{array}{l}\text { THR422 } \\
\text { (Theodore, ND) } \\
\text { Distance: } 170 \mathrm{~km} \\
\text { Elevation: } 0.85 \mathrm{~km} \\
\text { Lat: } 46.89^{\circ} \\
\text { Long: }-103.38^{\circ}\end{array}$ & $1998-2010$ & $\begin{array}{l}\text { MELA1 } \\
\text { (Medicine Lake, MT) } \\
\text { Distance: } 50 \mathrm{~km} \\
\text { Elevation : } 0.61 \mathrm{~km} \\
\text { Lat : } 48.49^{\circ} \\
\text { Long: }-104.48^{\circ}\end{array}$ & 2000-2010 \\
\hline $\begin{array}{l}\text { TBL } \\
\text { (Table Mountain, CO) } \\
\text { Elevation: } 1.69 \mathrm{~km} \\
\text { Lat: } 40.13^{\circ} \\
\text { Long: }-105.24^{\circ}\end{array}$ & 1996-2010 & 1997-2010 & $\begin{array}{l}\text { ROM406 } \\
\text { (Rocky Mtn. NP, } \\
\text { CO) } \\
\text { Distance: } 30 \mathrm{~km} \\
\text { Elevation: } 2.7 \mathrm{~km} \\
\text { Lat: } 40.28^{\circ} \\
\text { Long: }-105.55^{\circ}\end{array}$ & 1994-2010 & $\begin{array}{l}\text { ROMO1 } \\
\text { (Rocky Mon. NP, CO) } \\
\text { Distance: } 30 \mathrm{~km} \\
\text { Elevation: } 2.8 \mathrm{~km} \\
\text { Lat: } 40.28^{\circ} \\
\text { Long: }-105.55^{\circ}\end{array}$ & 1991-2008 \\
\hline $\begin{array}{l}\text { DRA } \\
\text { (Desert Rock, NV) } \\
\text { Elevation: } 1.01 \mathrm{~km} \\
\text { Lat: } 36.63^{\circ} \\
\text { Long: }-116.02^{\circ}\end{array}$ & 1999-2010 & 1999-2010 & $\begin{array}{l}\text { DEV412 } \\
\text { (Death Valley, CA) } \\
\text { Distance: } 85 \mathrm{~km} \\
\text { Elevation: } 0.12 \mathrm{~km} \\
\text { Lat: } 36.51^{\circ} \\
\text { Long: }-116.85^{\circ}\end{array}$ & $1995-2007$ & $\begin{array}{l}\text { DEVA1 } \\
\text { (Death Valley NP, CA) } \\
\text { Distance: } 85 \mathrm{~km} \\
\text { Elevation: } 0.13 \mathrm{~km} \\
\text { Lat: } 36.51^{\circ} \\
\text { Long: }-116.85^{\circ}\end{array}$ & 2000-2010 \\
\hline
\end{tabular}

effects on radiation and photolysis. In the coupled modeling system, CMAQ computes the concentration, composition, and size distribution of particulate matter (aerosol) in the atmosphere. The presence of aerosols in the atmosphere affects the radiation which in turn affects the photolysis rates which dictate atmospheric photo-chemistry, surface temperature that can affect thermally driven atmospheric chemi- cal reactions, planetary boundary layer height which dictates dilution and dispersion of pollutants, and even cloud formation. The response of the meteorological/WRF model to aerosol loading can be significant under conditions of significant pollution loading (Wang et al., 2014). In these feedback simulations, aerosol effects are treated dynamically where the CMAQ chemistry and radiation feedback modules are 
called every 5 and 20 WRF time steps, respectively. While the time step of WRF is $60 \mathrm{~s}$, the meteorology fields are updated from the feedback module every $20 \mathrm{~min}$. The AOD calculation in the model is based on Mie and core-shell scattering (Gan et al., 2014b) while the radiation calculation is based on a rapid radiative transfer model (RRTM). Four-dimensional data assimilation (FDDA) based on National Centers for Environmental Prediction (NCEP) Automated Data Processing (ADP) Operation Global Surface Observation (http://rda.ucar.edu/datasets/ds464.0/, last access: 10 June 2015) and NCEP ADP Global upper Air observational Weather Data (http://rda.ucar.edu/datasets/ds351.0/ \#!description, last access: 10 June 2015) is applied above the PBL (planetary boundary layer) using nudging coefficients of wind (guv), temperature (gt) and moisture (gq) (i.e., guv $=0.00005 \mathrm{~s}^{-1}, \mathrm{gt}=0.00005 \mathrm{~s}^{-1}$ and $\mathrm{gq}=0.00001 \mathrm{~s}^{-1}$ ) (Stauffer and Seaman, 1994; Pleim and Xiu, 2003; Pleim and Gilliam, 2009). These nudging coefficients are lower than the typical values used in standard WRF-CMAQ simulations in order to minimize the masking of the aerosol-direct feedback effects (difference between feedback and no feedback runs). Hogrefe et al. (2015) showed that these minimal nudging coefficients had very little effect on the magnitude of the aerosol-direct feedback effects compared to sensitivity simulations where no nudging was used but did lead to an improvement in model performance for temperature.

The WRF-CMAQ modeling system used in this study treats all relevant aerosol species, including sulfate, nitrate, ammonium, dust and organic aerosols. Likewise, the model also used a comprehensive emission data set (Xing et al., 2015) which included aerosol precursors and primary particulate matter. Additional details on the aerosol speciation represented in the CMAQ model can be found in Carlton et al. (2010), Foley et al. (2010), and Appel et al. (2013). Furthermore, Gan et al. (2014b) discuss how the optical properties and AOD are estimated based on the predicted spatially and temporally varying compositional characteristics which included the full suite of inorganic and organic constituents. However, in the analysis in this paper, we mainly focus on the change (i.e., reduction) of sulfate and nitrate which are the aerosol species most affected by emission reductions under the Clean Air Act and its amendments over the past 2 decades. The time varying chemical lateral boundary conditions (BC) were obtained from a $108 \mathrm{~km} \times 108 \mathrm{~km}$ WRFCMAQ hemispheric simulation (Xing et al., 2015). The details of the model parameterizations are listed in Table 2.

\subsection{Data analysis methodology}

First, the seven sites shown in Fig. 1 are separated into east and west regions. The results from each observation network are presented as time series of their network mean of the eastern US (i.e., averaging the annual mean of BON, GWN, PSU, and SGP to obtain the eastern network mean) and of the western US (i.e., averaging the annual mean of TBL, FPK, and
Table 2. List of model configuration.

\begin{tabular}{ll}
\hline Parameter & Configuration \\
\hline Emissions & Xing et al. (2013) \\
Planetary boundary layer & ACM2 (Pleim, 2007) \\
Microphysics & Morrison 2-moment scheme \\
Gas-phase chemistry & Carbon bond 06 \\
Aerosol chemistry & Carbon bond 06 \\
Surface layer & Pleim-Xiu \\
Cumulus & Kain-Fritsch (new Eta) \\
Radiation & RRTMG SW and LW \\
Land use & NLCD 50 \\
Boundary conditions & Hemispheric WRF-CMAQ \\
& simulation from Xing et al. (2014) \\
\hline
\end{tabular}

DRA to obtain the western network mean). Note that they are shown as annual mean anomalies except AOD. Specific time series trends at each site for different observed variables can be found in Gan et al. (2014a). The same averaging technique is applied to the model output and emission data set. Model data is extracted from the grid cell where the site is located. After that, least-square fits (LSFs) are applied to both eastern and western network means for observations, model output, and emissions to determine the trends individually.

To ensure the estimated trends are statistically significant, a regression analysis is used to account for autocorrelation and variability in both observed and modeled data. This statistical methodology is constructed from Weatherhead et al. (1998), the general principle and its application can be found in Gan et al. (2014a). Note that the significance of the trend can be calculated using the ratio of the absolute trend relative to its uncertainty estimate. This ratio is assumed to be approximately normally distributed with a mean of zero and standard deviation of 1 . Thus, if this ratio is 1.96 or greater, the trend is significant at the $95 \%$ confidence level. In the same way, if this ratio is greater than 1.65 , the trend is significant at the $90 \%$ confidence level. The term "significant" in this study indicates that the estimated trend is statistically significantly different from zero at the given confidence level.

In addition to the time series and trends at specific modeling locations, our analysis also includes maps of trends in annual mean values calculated from the 1995-2010 WRFCMAQ simulations over the CONUS domain overlaid with circles representing observed trends from the seven selected sites for each network. The size of the circle in Figs. 4, 5, 6, and 9 represents the level of the significance (e.g., the bigger the circle, the higher the significance). An analysis of the entire US for the whole 16-year period (except AOD is represented by the last 14 years) provides a better overall understanding of the spatial extent of the effects of the CAA implementation across the US than just the seven groups of sites. 

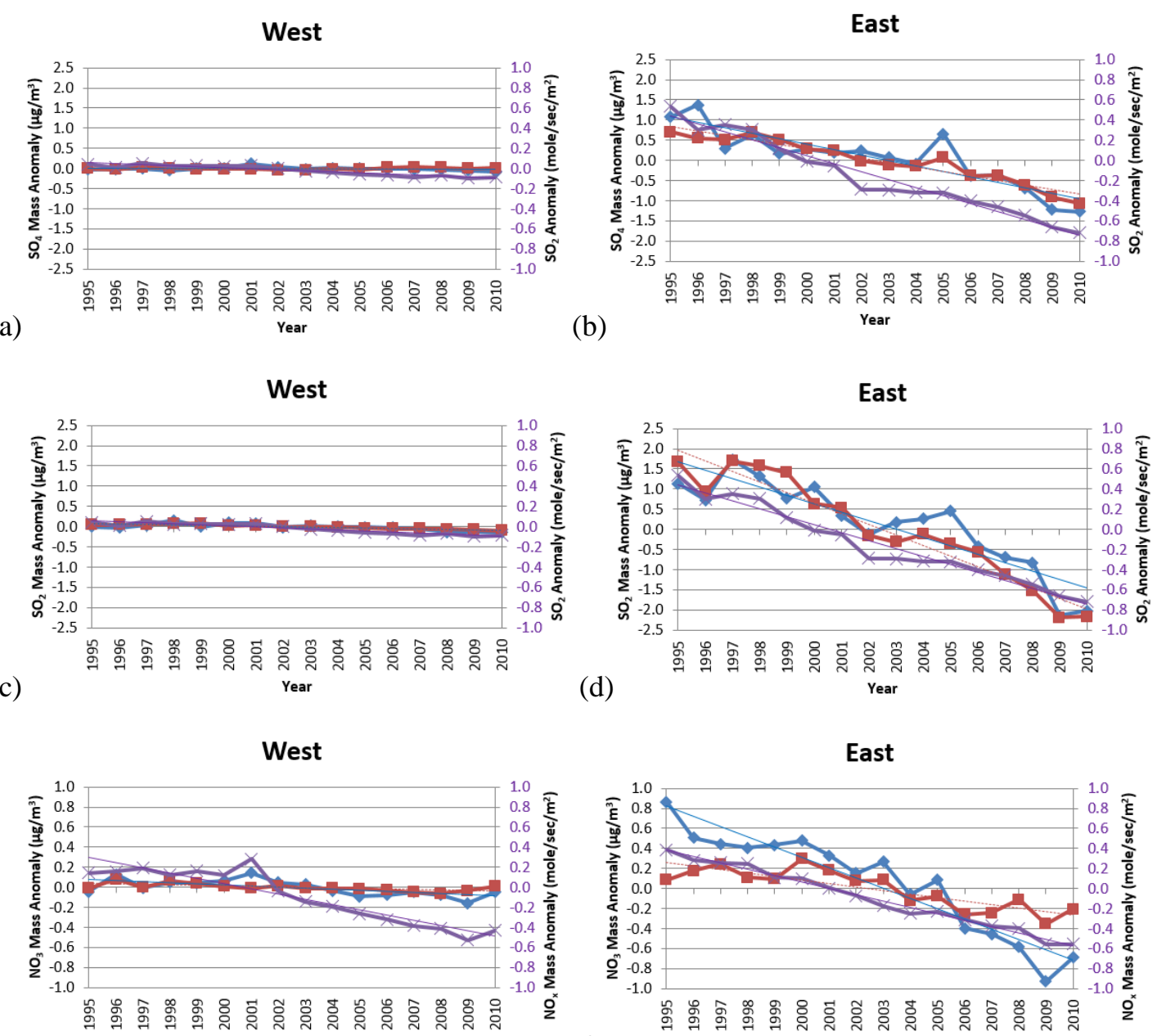

(e)

Year

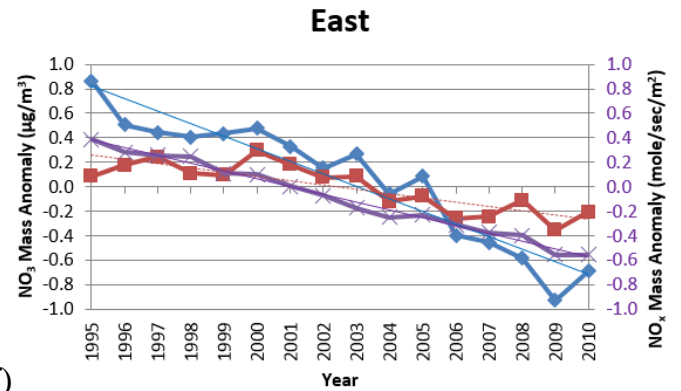

Figure 2. Annual mean anomalies of 1995-2010 $\mathrm{SO}_{4}^{2-}$ (top panels), $\mathrm{SO}_{2}$ (middle panels), and $\mathrm{NO}_{3}^{-}$(bottom panels) for CASTNET observations (blue line - primary y axis), model simulations (red line - primary y axis), and emissions (purple line - secondary $y$ axis). Least-square fit trend lines are also shown for each time series. Note that $\mathrm{SO}_{2}$ emissions are paired with both $\mathrm{SO}_{2}$ and $\mathrm{SO}_{4}^{2-}$ concentrations since most of the atmospheric $\mathrm{SO}_{4}^{2-}$ burden is due to secondary formation from $\mathrm{SO}_{2}$ rather than primary emissions of particulate $\mathrm{SO}_{4}^{2-}$. The left column represents the western US while the right column represents the eastern US.

\section{Results}

\subsection{Trends in aerosol concentrations}

Since this study attempts to determine the aerosol radiative effects, the following discussion focusses only on the feedback simulations. First, the observed and modeled surface aerosol and gas concentrations are assessed at the CASTNET and IMPROVE monitors. Their time series trends are presented in Figs. 2 and 3, respectively. As illustrated in Fig. 2a$\mathrm{f}$, the locations of the CASTNET monitors in the western US show small, decreasing, or almost no trends in observations, model, and emissions for all species (i.e., sulfur dioxide, $\mathrm{SO}_{2}$, sulfate, $\mathrm{SO}_{4}^{2-}$, and nitrate, $\mathrm{NO}_{3}^{-}$) while more dramatic decreasing trends are noted at the eastern US sites. This finding is not surprising because the implementation of the CAA reduced emissions and consequently ambient air pollutants in source regions predominantly located in the eastern US (e.g., targeted at areas exceeding the NAAQS). In contrast, air pollution concentrations were low at the rural western monitors from the beginning resulting in the noted weaker trend (Gan et al., 2014a). Therefore, more dramatic decreasing trends are observed in the eastern US. The calculated trends are summarized in Table 3. The results listed in this table show that the model output and emissions exhibit decreasing trends which are in line with CASTNET measurements except for $\mathrm{SO}_{4}^{2-}$ in the western US where the simulations show a decrease and the observations show an increase. However, note that the $\mathrm{SO}_{4}^{2-}$ trends from the model and observations are both very close to zero in this region. In Fig. 3a-f and Table 4, similar trends (i.e., decreasing or almost no trend) are observed in measurements, model output, and emissions for $\mathrm{SO}_{4}^{2-}, \mathrm{NO}_{3}^{-}$, 
West

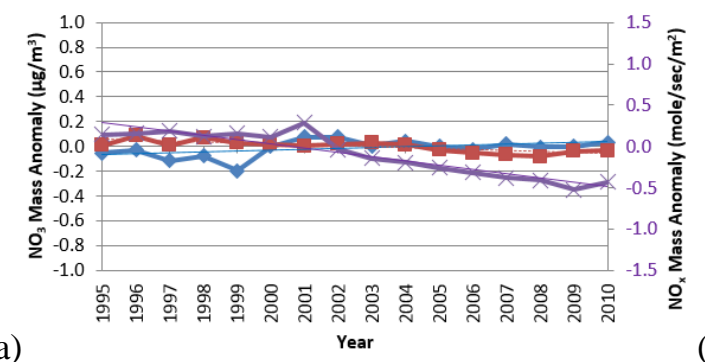

(a)

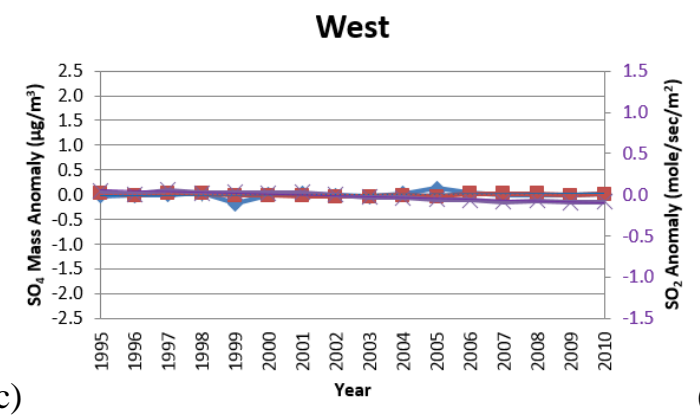

(c)

WEST

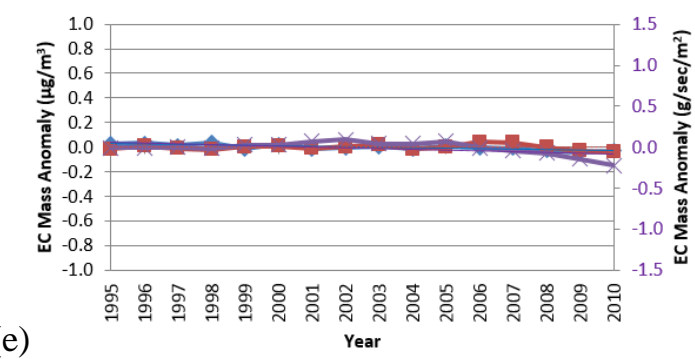

East

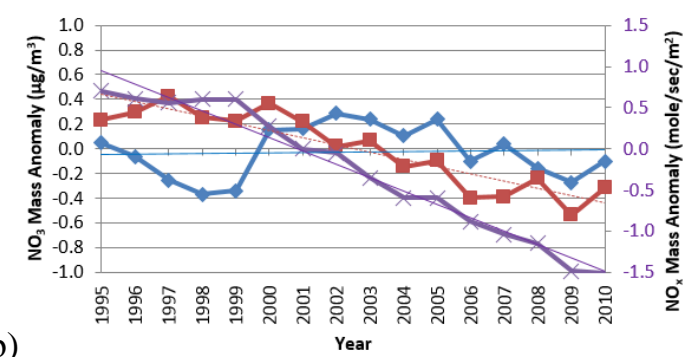

East

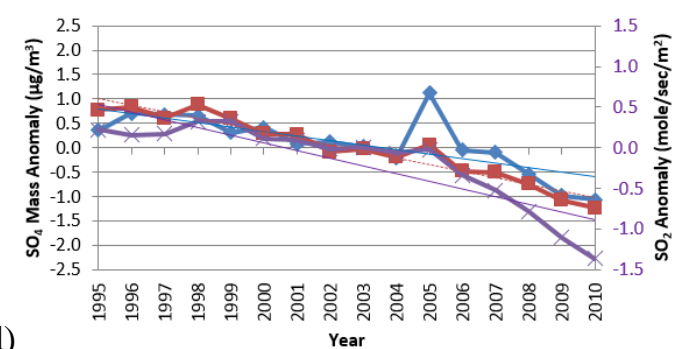

EAST

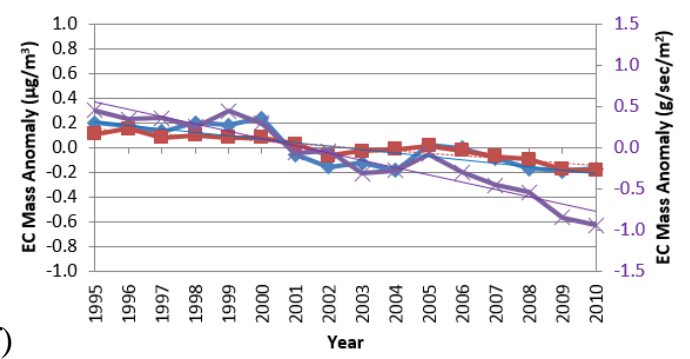

Figure 3. Annual mean anomalies of 1995-2010 $\mathrm{NO}_{3}^{-}$(top panels), $\mathrm{SO}_{4}^{2-}$ (middle panels), and EC (bottom panels) for IMPROVE observations (blue line - primary $y$ axis), model simulations (red line - primary $y$ axis), and emissions (purple line - secondary $y$ axis). Least-square fit trend lines are also shown for each time series. Note that $\mathrm{SO}_{2}$ emissions are paired with both $\mathrm{SO}_{2}$ and $\mathrm{SO}_{4}$ concentrations since most of the atmospheric $\mathrm{SO}_{4}^{2-}$ burden is due to secondary formation from $\mathrm{SO}_{2}$ rather than primary emissions of particulate $\mathrm{SO}_{4}^{2-}$. The left column represents the western US while the right column represents the eastern US.

and element carbon (EC) at the IMPROVE monitor locations. Overall, the model trend predictions match (see Table 6 for entire network correlation coefficients: $R>0.8$ for each variable except diffuse radiation) the surface observation trends for both networks, especially for $\mathrm{SO}_{4}^{2-}$. This demonstrates that the coupled WRF-CMAQ model exhibits skill in replicating the long-term trends of anthropogenic aerosol loadings, thereby providing confidence for examining trends in aerosol-direct effects.

To assess the effects of reductions in anthropogenic emissions resulting from the implementation of the CAA during 1995-2010, the modeled trends in annual means across the entire CONUS domain for all species are presented in Fig. $4 \mathrm{a}-\mathrm{f}$ along with observed trends at the seven sites (colorcoded circles) from the CASTNET and IMPROVE networks. In general, at the location of the observations (circles), the modeled and observed trends are similar in direction and magnitude (i.e., similar color code). As shown in Fig. 4a$\mathrm{f}$, more substantial reductions are noted in the eastern US, in particular for sulfate. Again this result validates previous findings and indicates that there is a possibility of aerosoldirect effect-induced "brightening" in the US over the past 16 years (Gan et al., 2014a).

Before examining the total AOD, the $\mathrm{PM}_{2.5}$ concentrations from IMPROVE are evaluated to gain some insight into the change in the total particulate matter burden resulting from air pollution controls. In Fig. 5a and b, time series of annual mean $\mathrm{PM}_{2.5}$ from observations (blue line) and model simulations (red line) are presented together with (Fig. 5c) a map of the modeled and observed trends across the entire CONUS domain. The modeled trends are consistent with observations (see Tables 4 and 6). A small or nearly no trend is seen in the 
Table 3. Trends of 16 years for CASTNET observations, aerosol feedback (FB) simulation, and emissions. The table also shows the uncertainty estimates of the trends (standard error, SE), the ratio of the absolute trends relative to their uncertainty estimate, and the confidence level based on the method described in Weatherhead et al. (1998) and Gan et al. (2014a).

\begin{tabular}{|c|c|c|c|c|c|c|c|c|}
\hline \multirow{3}{*}{$\begin{array}{l}\text { CASTNET } \\
\left(\mu \mathrm{g} \mathrm{m}^{-3}\right)\end{array}$} & \multicolumn{8}{|c|}{ East } \\
\hline & \multicolumn{4}{|c|}{ Observations } & \multicolumn{4}{|c|}{ Simulation (FB) } \\
\hline & trend & SE & $\frac{|\hat{m}|}{\sigma_{m}}$ & $\begin{array}{r}\text { confidence } \\
\text { level }\end{array}$ & trend & SE & $\frac{|\hat{m}|}{\sigma_{m}}$ & $\begin{array}{r}\text { confidence } \\
\text { level }\end{array}$ \\
\hline $\mathrm{SO}_{4}^{2-}$ & -0.1346 & 0.0056 & 23.8675 & $>95$ & -0.1115 & 0.0032 & 34.8830 & $>95$ \\
\hline $\mathrm{SO}_{2}$ & -0.2089 & 0.0107 & 19.4757 & $>95$ & -0.2624 & 0.0078 & 33.7830 & $>95$ \\
\hline $\mathrm{NO}_{3}^{-}$ & -0.1026 & 0.0034 & 30.4293 & $>95$ & -0.0348 & 0.0019 & 18.5530 & $>95$ \\
\hline \multirow[t]{2}{*}{ CASTNET } & \multicolumn{8}{|c|}{ West } \\
\hline & \multicolumn{4}{|c|}{ Observations } & \multicolumn{4}{|c|}{ Simulation (FB) } \\
\hline$\left(\mu \mathrm{g} \mathrm{m}^{-3}\right)$ & trend & SE & $\frac{|\hat{m}|}{\sigma_{m}}$ & $\begin{array}{r}\text { confidence } \\
\text { level }\end{array}$ & trend & SE & $\frac{|\hat{m}|}{\sigma_{m}}$ & $\begin{array}{r}\text { confidence } \\
\text { level }\end{array}$ \\
\hline $\mathrm{SO}_{4}^{2-}$ & -0.0026 & 0.0010 & 2.5329 & $>95$ & 0.0010 & 0.0005 & 1.8118 & $>90$ \\
\hline $\mathrm{SO}_{2}$ & -0.0121 & 0.0012 & 10.3122 & $>95$ & -0.0108 & 0.0004 & 28.0550 & $>95$ \\
\hline $\mathrm{NO}_{3}^{-}$ & -0.1100 & 0.0010 & 10.7925 & $>95$ & -0.0052 & 0.0003 & 14.9930 & $>95$ \\
\hline Emissions & \multicolumn{4}{|c|}{ East } & \multicolumn{4}{|c|}{ West } \\
\hline$\left(\right.$ mole s $\left.{ }^{-1} \mathrm{~m}^{-2}\right)$ & trend & SE & $\frac{|\hat{m}|}{\sigma_{m}}$ & $\begin{array}{r}\text { confidence } \\
\text { level }\end{array}$ & trend & SE & $\frac{|\hat{m}|}{\sigma_{m}}$ & $\begin{array}{r}\text { confidence } \\
\text { level }\end{array}$ \\
\hline $\mathrm{SO}_{2}$ & -0.0792 & 0.0016 & 49.0140 & $>95$ & -0.0102 & 0.0003 & 29.5820 & $>95$ \\
\hline $\mathrm{NO}_{x}$ & -0.0636 & 0.0005 & 140.7900 & $>95$ & -0.0522 & 0.0024 & 21.4980 & $>95$ \\
\hline
\end{tabular}

western US while a dramatic decreasing trend is evident in the eastern US and illustrates the effectiveness of air pollution controls strategies in improving the air quality over large portions of the US.

\subsection{Trends in aerosol optical depth (AOD) and SW radiation}

As a result of the reduction in the tropospheric particulate matter burden, the AOD was reduced in the eastern US over the 14-year period (1997-2010) as illustrated in Fig. 6a-c. However, the AOD in the western US shows very little change over this period. Even though the modelpredicted AOD is underestimated relative to the observations (see Fig. 6a, b and Table 5), the model is still able to capture trends similar to observations, especially in the eastern US (obs_west: 0.0009 year $^{-1}$, sim_west: 0.0001 year $^{-1}$ and obs_east: -0.0012 year $^{-1}$, sim_east: -0.0017 year $\left.^{-1}\right)$. As stated in Gan et al. (2014b), several possible reasons for this model AOD underestimation are the underestimation of specific aerosol constituents such as organic carbon, low sea-salt concentration in the accumulation mode, and uncertainties in characterizing the water soluble potion of the organic carbon leading to poor representation of refractive indices of organic aerosol. Furthermore, the hygroscopic effects of water solu- ble organic carbon and external mixing are not considered in the current version of the WRF-CMAQ model. The omitted effects and incomplete representation of mixing state can play an important role in the apportionment of extinction. (Gan et al., 2014b; Curci et al., 2015). Another WRF-CMAQ evaluation study by Hogrefe et al. (2015) found that the underestimation of AOD occurs throughout all seasons despite the fact that the analysis of $24 \mathrm{~h}$ average surface $\mathrm{PM}_{2.5}$ predictions (see Table 1 in Hogrefe et al., 2015) indicate overestimations of $\mathrm{PM}_{2.5}$ during winter but largely unbiased $\mathrm{PM}_{2.5}$ prediction during summer. Note that the $\mathrm{PM}_{2.5}$ concentration in this study represents the ground-level measurement while the AOD is an integration of aerosol extinction over a vertical column. Model predicted aerosol extinction in any one layer depends on aerosol concentrations and properties together with relative humidity; therefore, differences in the vertical distribution of modeled aerosol concentrations and relative humidity would result in different calculated AOD even if $\mathrm{PM}_{2.5}$ column mass was consistent with observations.

As discussed by Gan et al. (2014a), the "brightening" effects are evident in the observed all-sky and clear-sky total SW radiation trends and this finding was confirmed by the model results as illustrated in Fig. 7a and b and Fig. 8a and b. Stronger and better agreement is noted in the all-sky SW radiation trend (see Fig. 9a and Tables 5 and 6) while there 


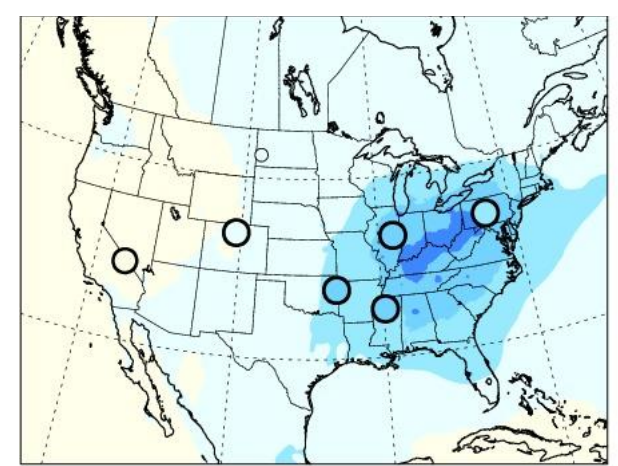

(a)

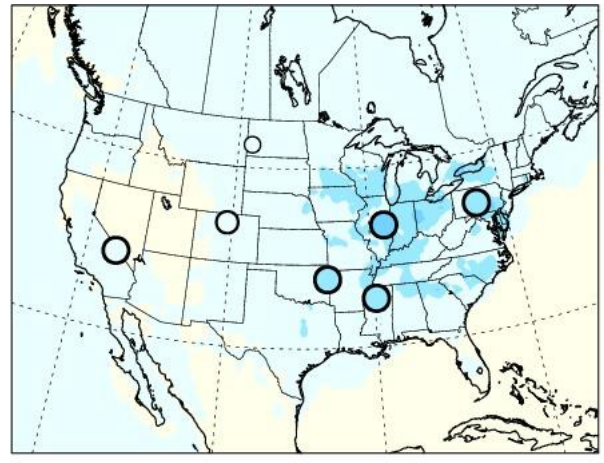

(c)

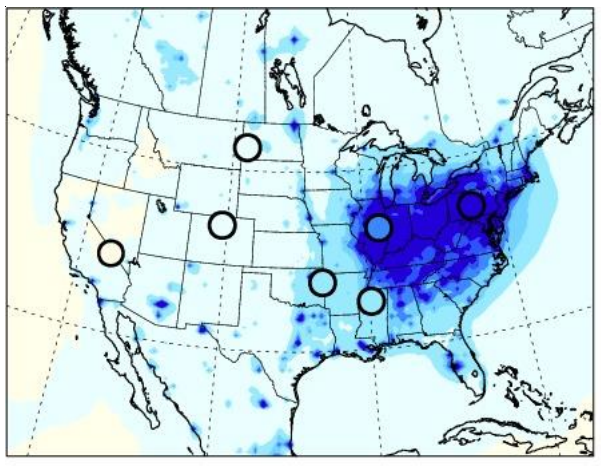

(e)

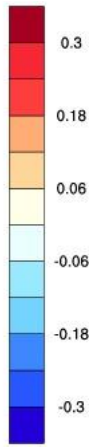

(b)

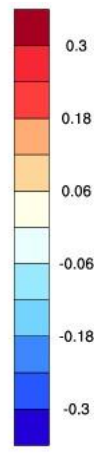

(d)

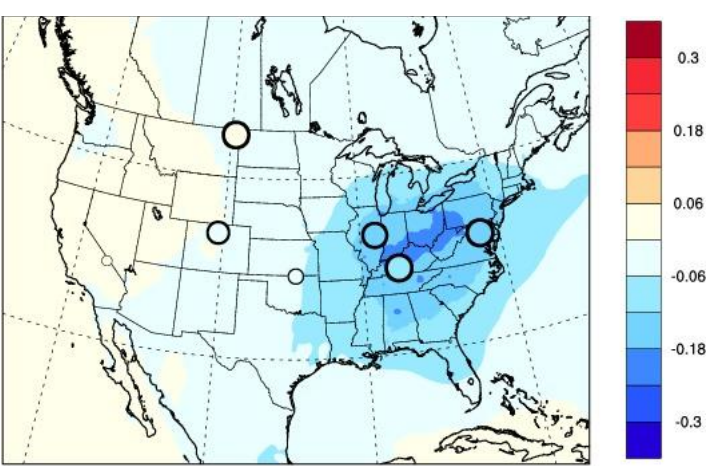

Min:-.2558 Max: 0296

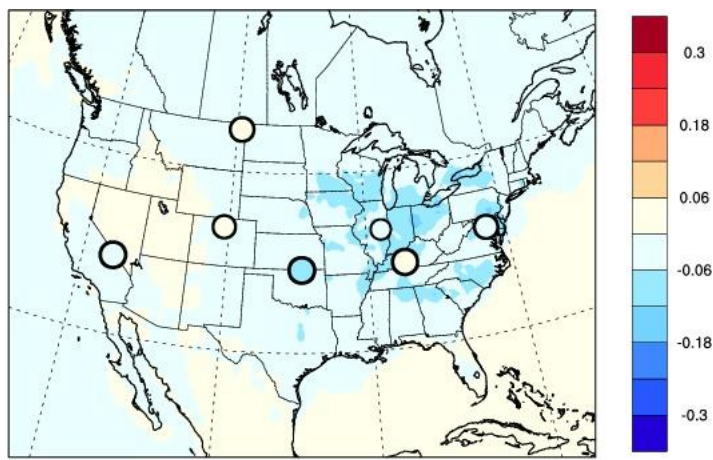

Min: - 2001 Max: .0213

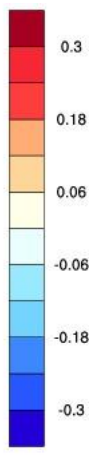

(f)

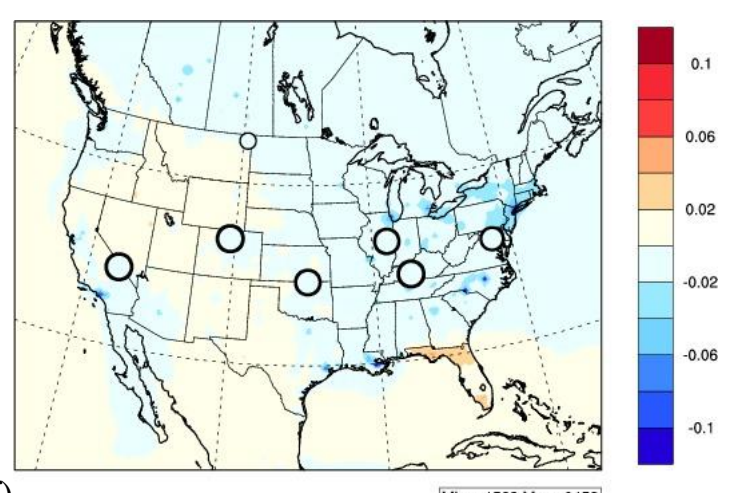

Figure 4. Map of annual trends based on 1995-2010 coupled WRF-CMAQ simulations over the CONUS domain are depicted along with circles representing observed trends for seven sites. Left column for $\mathrm{SO}_{4}^{2-}$ (top panels), $\mathrm{NO}_{3}^{-}$(middle panels), and $\mathrm{SO}_{2}$, (bottom panels) from the CASTNET network while the right column is for $\mathrm{SO}_{4}^{2-}$ (top panels), $\mathrm{NO}_{3}^{-}$(middle panels), and EC (bottom panels) from the IMPROVE network. Note that the size of the circle represents the level of the significance. A larger circle indicates more significance.

is a weaker model trend and less agreement in the clear-sky SW radiation (see Fig. 9b and Tables 5 and 6). As shown in Table 5, the "brightening" occurs in the all-sky SW radiation while the cloudiness of both model and observations exhibits decreasing trends indicating the possibility that semi-indirect and/or indirect effects of decreasing aerosols may be a contributing factor. Aerosols can interact with clouds and precipitation in many ways, acting either as cloud condensation nuclei or ice nuclei, or as absorbing particles, redistributing solar energy as thermal energy inside cloud layers. In other words, a decreasing troposphere burden of aerosols can cause a decrease of averaged cloud cover, and then this effect leads to more solar radiation reaching the surface. However, trends in cloud cover can be influenced by many other factors which are very difficult to quantify based solely on available observational information. A better representation of clouds is needed for the model. We also note that trends in both allsky trends with (FB) and without (NFB) aerosol-direct feedback for model prediction are very similar but that the simulation with aerosol-direct effect predicts a trend modestly 
West

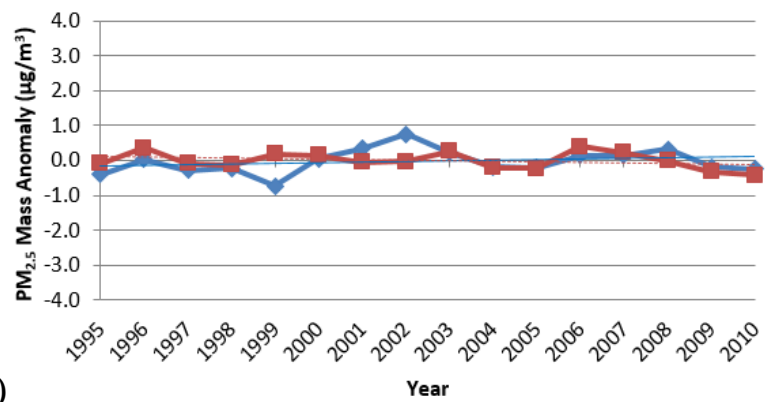

East

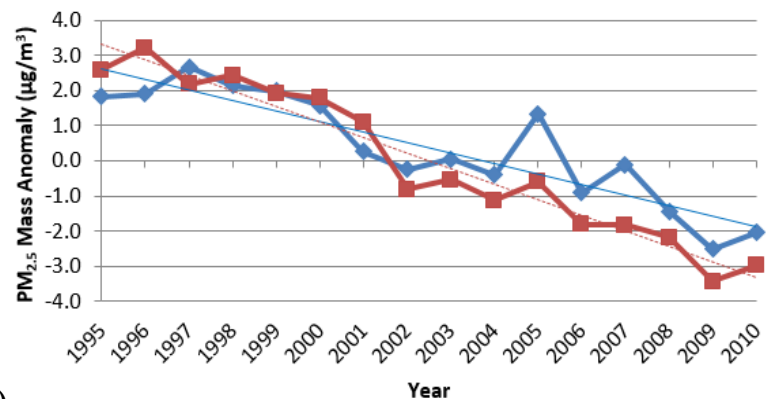

(b)

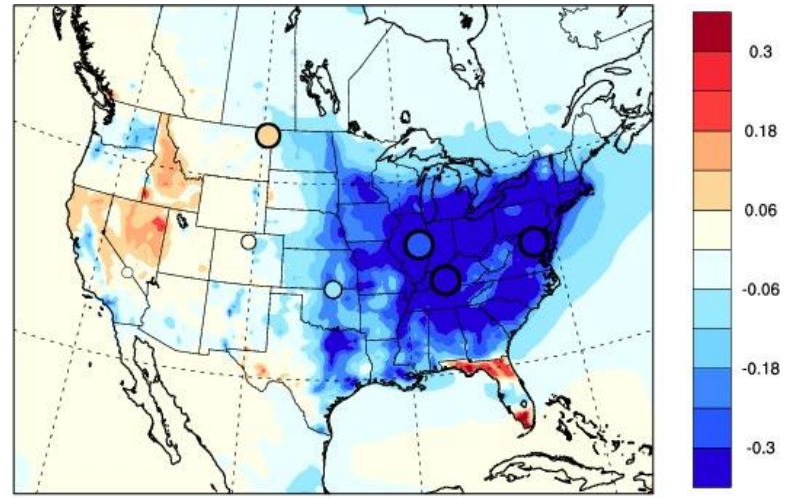

(c)

Min:-,9276 Max: .4506

Figure 5. Annual mean anomalies of 1995-2010 $\mathrm{PM}_{2.5}$ in the (a) western and (b) eastern US from IMPROVE for observations (blue line) and model simulations (red line). Least-squares fit trend lines are also shown for each time series. (c) Map of $\mathrm{PM}_{2.5}$ annual trends based on 1995-2010 coupled WRF-CMAQ simulations over the CONUS domain depicted along with circles representing the observed trends for seven sites. Note that the size of the circle represents the level of the significance. A larger circle indicates more significance.

closer to the observed trend in the eastern US (obs_east: $0.6296 \mathrm{~W} \mathrm{~m}^{-2}$ year $^{-1}$, simFB_east: $0.4678 \mathrm{~W} \mathrm{~m}^{-2}$ year $^{-1}$, and simNFB_east: $0.4148 \mathrm{~W} \mathrm{~m}^{-2}$ year $^{-1}$ ) while the aerosoldirect effect is less apparent in the western US (obs_west: $0.5131 \mathrm{~W} \mathrm{~m}^{-2}$ year $^{-1}$, simFB_west: $0.2389 \mathrm{~W} \mathrm{~m}^{-2}$ year $^{-1}$ and simNFB_west: $0.2877 \mathrm{~W} \mathrm{~m}^{-2}$ year $^{-1}$ ). Aerosol indirect
West

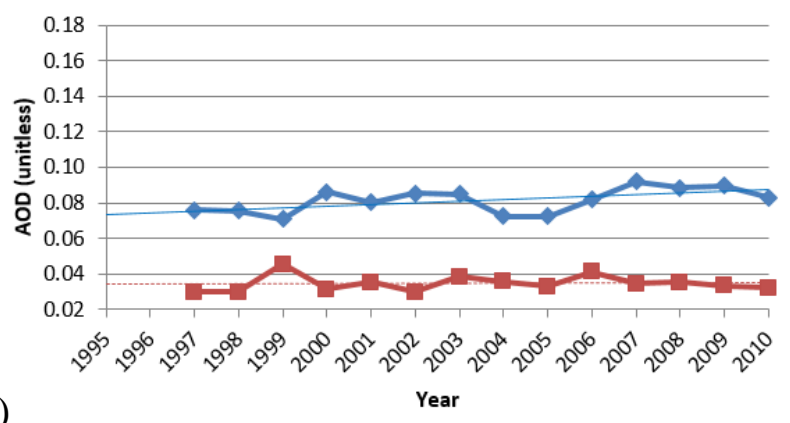

East

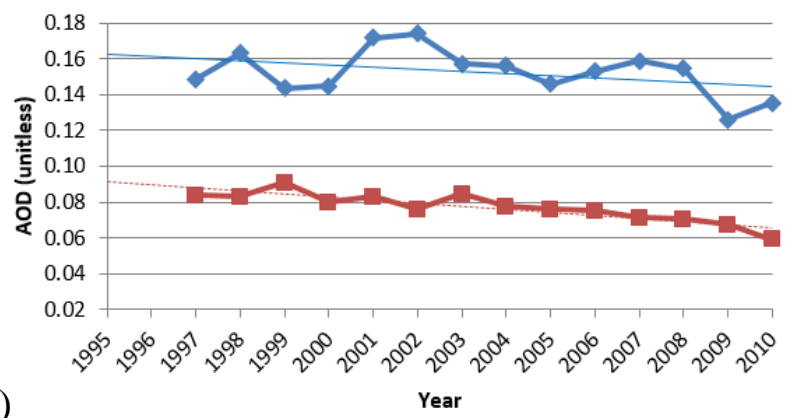

(b)

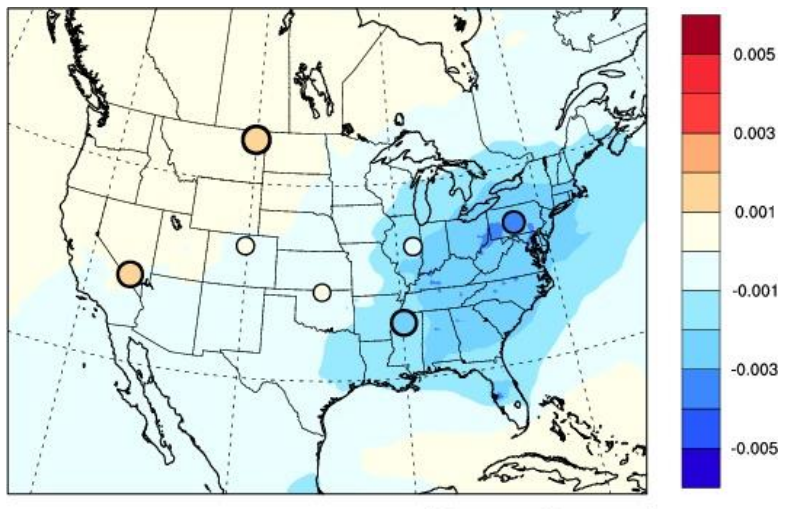

(c)

Min: - 004588 Max: .001004

Figure 6. Annual mean of 1997-2010 AOD in the (a) western and (b) eastern US from SURFRAD for observations (blue line) and model simulations (red line). Least-squares fit trend lines are also shown for each time series. (c) Map of AOD annual trends based on 1997-2010 coupled WRF-CMAQ simulations over the CONUS domain depicted along with circles representing observed trends for seven sites. Note that the size of the circle represents the level of the significance. A larger circle indicates more significance.

effects have recently been included in the WRF-CMAQ model (Yu et al., 2014), and implementing the aerosol indirect effect may help to improve the simulation of all-sky SW total, direct, and diffuse trends and this will be investigated in future analysis. 
Table 4. Trends of 16 years for IMPROVE observations, aerosol feedback (FB) simulation, and emissions. The table also shows the uncertainty estimates of the trends (standard error, SE), the ratio of the absolute trends relative to their uncertainty estimate, and the confidence level based on the method described in Weatherhead et al. (1998) and Gan et al. (2014a).

\begin{tabular}{|c|c|c|c|c|c|c|c|c|}
\hline \multirow{3}{*}{$\begin{array}{l}\text { IMPROVE } \\
\left(\mu \mathrm{g} \mathrm{m}^{-3}\right)\end{array}$} & \multicolumn{8}{|c|}{ East } \\
\hline & \multicolumn{4}{|c|}{ Observations } & \multicolumn{4}{|c|}{ Simulation (FB) } \\
\hline & trend & SE & $\frac{|\hat{m}|}{\sigma_{m}}$ & $\begin{array}{r}\text { confidence } \\
\text { level }\end{array}$ & trend & SE & $\frac{|\hat{m}|}{\sigma_{m}}$ & $\begin{array}{r}\text { confidence } \\
\text { level }\end{array}$ \\
\hline $\mathrm{SO}_{4}$ & -0.0933 & 0.0071 & 13.1013 & $>95$ & -0.1358 & 0.0029 & 47.3720 & $>95$ \\
\hline $\mathrm{NO}_{3}$ & 0.0025 & 0.0065 & 0.3906 & $<90$ & -0.0585 & 0.0020 & 28.9020 & $>95$ \\
\hline $\mathrm{EC}$ & -0.0106 & 0.0014 & 7.7710 & $>95$ & -0.0195 & 0.0008 & 24.6109 & $>95$ \\
\hline $\mathrm{PM}_{2.5}$ & -0.2998 & 0.0114 & 26.3410 & $>95$ & -0.4419 & 0.0072 & 61.3020 & $>95$ \\
\hline \multirow[t]{2}{*}{ IMPROVE } & \multicolumn{8}{|c|}{ West } \\
\hline & \multicolumn{4}{|c|}{ Observations } & \multicolumn{4}{|c|}{ Simulation (FB) } \\
\hline$\left(\mu \mathrm{g} \mathrm{m}^{-3}\right)$ & trend & SE & $\frac{|\hat{m}|}{\sigma_{m}}$ & $\begin{array}{r}\text { confidence } \\
\text { level }\end{array}$ & trend & SE & $\frac{|\hat{m}|}{\sigma_{m}}$ & $\begin{array}{r}\text { confidence } \\
\text { level }\end{array}$ \\
\hline $\mathrm{SO}_{4}$ & 0.0038 & 0.0009 & 4.3870 & $>95$ & -0.0006 & 0.0005 & 1.3370 & $<90$ \\
\hline $\mathrm{NO}_{3}$ & 0.0069 & 0.0013 & 5.3737 & $>95$ & -0.0078 & 0.0004 & 19.0980 & $>95$ \\
\hline EC & -0.0033 & 0.0001 & 26.1560 & $>95$ & -0.0001 & 0.0005 & 0.2313 & $<90$ \\
\hline $\mathrm{PM}_{2.5}$ & 0.0181 & 0.0074 & 2.4442 & $>95$ & -0.0151 & 0.0037 & 4.0741 & $>95$ \\
\hline Emissions & \multicolumn{4}{|c|}{ East } & \multicolumn{4}{|c|}{ West } \\
\hline$\left(\right.$ mole $\left.\mathrm{s}^{-1} \mathrm{~m}^{-2}\right)$ & trend & SE & $\frac{|\hat{m}|}{\sigma_{m}}$ & $\begin{array}{r}\text { confidence } \\
\text { level }\end{array}$ & trend & SE & $\frac{|\hat{m}|}{\sigma_{m}}$ & $\begin{array}{r}\text { confidence } \\
\text { level }\end{array}$ \\
\hline $\mathrm{SO}_{2}$ & -0.0941 & 0.0118 & 7.9968 & $>95$ & -0.0102 & 0.0003 & 29.5810 & $>95$ \\
\hline $\mathrm{NO}_{x}$ & -0.1628 & 0.0038 & 42.8840 & $>95$ & -0.0519 & 0.0024 & 21.4580 & $>95$ \\
\hline EC & -0.0889 & 0.0030 & 29.6640 & $>95$ & -0.0090 & 0.0033 & 2.7338 & $>95$ \\
\hline
\end{tabular}
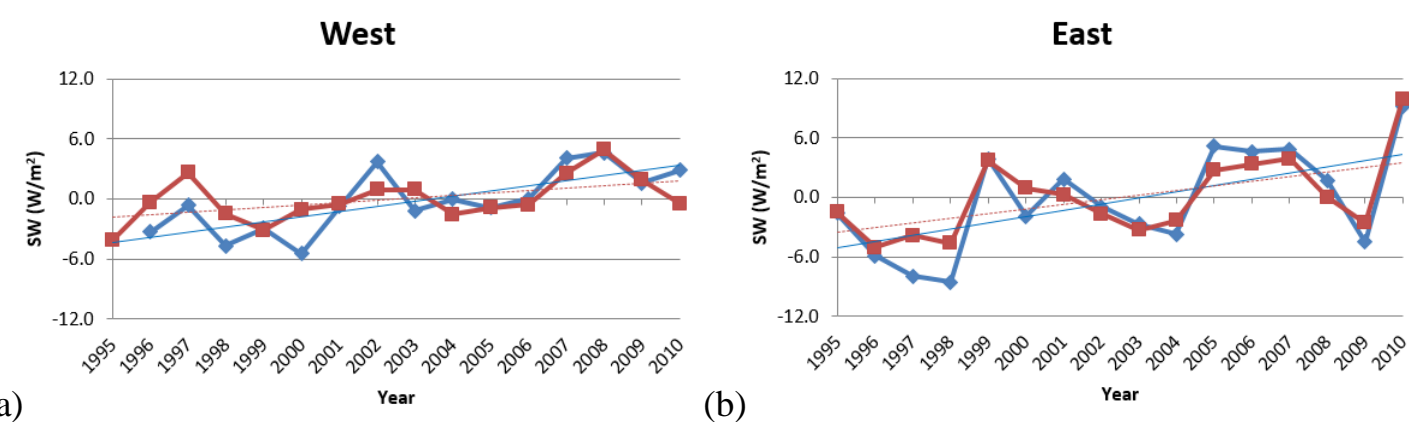

(b)

Figure 7. Annual mean anomalies of 1995-2010 all-sky total SW radiation for SURFRAD observations (blue line) and model simulations (red line). Least-square fit trend lines are also shown for each time series. The left column represents the western US while the right column represents the eastern US.

In order to better examine the aerosol-direct effect, the following discussion focuses on clear-sky SW radiation. The trend of the clear-sky SW radiation from the model is underestimated compared to the observations and overestimated for the direct and diffuse components especially, for the east. One of the potential causes of this underestimation maybe related to the underestimation of particulate matter concentra- tion and AOD (Gan et al., 2014b; Curci et al., 2015; Hogrefe et al., 2015). Another possible source of disagreement between modeled and observed trends in the clear-sky direct and diffuse components is not accounting for possible clearsky "whitening", proposed by Long et al. (2009) and mentioned by Gan et al. (2014a), which acts to repartition the 
Table 5. Trends of 16 years for SURFRAD observations, aerosol feedback (FB), and no aerosol feedback (NFB) simulations. The table also shows the uncertainty estimates of the trends, the ratio of the absolute trends relative to their uncertainty estimate, and the confidence level based on the method described in Weatherhead et al. (1998) and Gan et al. (2014a).

\begin{tabular}{|c|c|c|c|c|c|c|c|c|c|c|c|c|}
\hline \multirow[t]{3}{*}{ SURFRAD } & \multicolumn{12}{|c|}{ East } \\
\hline & \multicolumn{4}{|c|}{ Observations } & \multicolumn{4}{|c|}{ Simulation (FB) } & \multicolumn{4}{|c|}{ Simulation (NFB) } \\
\hline & trend & SE & $\frac{|\hat{m}|}{\sigma_{m}}$ & $\begin{array}{r}\text { confidence } \\
\text { level }\end{array}$ & trend & SE & $\frac{|\hat{m}|}{\sigma_{m}}$ & $\begin{array}{r}\text { confidence } \\
\text { level }\end{array}$ & trend & SE & $\frac{|\hat{m}|}{\sigma_{m}}$ & $\begin{array}{r}\text { confidence } \\
\text { level }\end{array}$ \\
\hline $\begin{array}{l}\text { SW } \\
\left(\mathrm{W} \mathrm{m}^{-2} \text { year }^{-1}\right)\end{array}$ & 0.6296 & 0.0566 & 11.1315 & $>95$ & 0.4678 & 0.0476 & 9.8347 & $>95$ & 0.4148 & 0.0547 & 7.5757 & $>95$ \\
\hline $\begin{array}{l}\text { SWC } \\
\left(\mathrm{W} \mathrm{m}^{-2} \text { year }^{-1}\right)\end{array}$ & 0.3691 & 0.0292 & 12.6481 & $>95$ & 0.1242 & 0.0099 & 12.5670 & $>95$ & 0.0006 & 0.0036 & 0.1786 & $<90$ \\
\hline $\begin{array}{l}\text { SW DIR } \\
\left(\mathrm{W} \mathrm{m}^{-2} \text { year }^{-1}\right)\end{array}$ & 0.4149 & 0.0576 & 7.2066 & $>95$ & 0.8364 & 0.0746 & 11.2120 & $>95$ & 0.6817 & 0.0930 & 7.3320 & $>95$ \\
\hline $\begin{array}{l}\text { SW DIF } \\
\left(\mathrm{W} \mathrm{m}^{-2} \text { year }^{-1}\right)\end{array}$ & 0.2555 & 0.0235 & 10.8605 & $>95$ & -0.3589 & 0.0270 & 13.3040 & $>95$ & -0.2586 & 0.0361 & 7.1687 & $>95$ \\
\hline $\begin{array}{l}\text { SWC DIR } \\
\left(\mathrm{W} \mathrm{m}^{-2} \text { year }^{-1}\right)\end{array}$ & -0.0085 & 0.0315 & 0.2701 & $<90$ & 0.5810 & 0.0244 & 23.7720 & $>95$ & 0.0038 & 0.0040 & 0.9496 & $<90$ \\
\hline $\begin{array}{l}\text { SWC DIF } \\
\left(\mathrm{W} \mathrm{m}^{-2} \text { year }^{-1}\right)\end{array}$ & 0.3764 & 0.0107 & 35.1138 & $>95$ & -0.4569 & 0.0142 & 32.0910 & $>95$ & -0.0031 & 0.0005 & 5.9625 & $>95$ \\
\hline $\begin{array}{l}\text { AOD } \\
\text { (unitless) }\end{array}$ & -0.0012 & 0.0003 & 4.2559 & $>95$ & -0.0017 & 0.00005 & 30.7585 & $>95$ & & & & \\
\hline $\begin{array}{l}\text { Cloudiness } \\
\text { (unitless) }\end{array}$ & -0.0021 & 0.0003 & 6.1257 & $>95$ & -0.0034 & 0.0004 & 7.6943 & $>95$ & & & & \\
\hline \multirow[t]{3}{*}{ SURFRAD } & \multicolumn{12}{|c|}{ West } \\
\hline & \multicolumn{4}{|c|}{ Observations } & \multicolumn{4}{|c|}{ Simulation (FB) } & \multicolumn{4}{|c|}{ Simulation (NFB) } \\
\hline & trend & SE & $\frac{|\hat{m}|}{\sigma_{m}}$ & $\begin{array}{r}\text { confidence } \\
\text { level }\end{array}$ & trend & SE & $\frac{|\hat{m}|}{\sigma_{m}}$ & $\begin{array}{r}\text { confidence } \\
\text { level }\end{array}$ & trend & SE & $\frac{|\hat{m}|}{\sigma_{m}}$ & $\begin{array}{r}\text { confidence } \\
\text { level }\end{array}$ \\
\hline $\begin{array}{l}\text { SW } \\
\left(\mathrm{W} \mathrm{m}^{-2} \text { year }^{-1}\right)\end{array}$ & 0.5131 & 0.0359 & 14.2751 & $>95$ & 0.2389 & 0.0371 & 6.4364 & $>95$ & 0.2877 & 0.0362 & 7.9451 & $>95$ \\
\hline $\begin{array}{l}\text { SWC } \\
\left(\mathrm{W} \mathrm{m}^{-2} \text { year }^{-1}\right)\end{array}$ & 0.4799 & 0.0443 & 10.8243 & $>95$ & 0.0148 & 0.0144 & 1.0263 & $<90$ & 0.0506 & 0.0062 & 8.1029 & $>95$ \\
\hline $\begin{array}{l}\text { SW DIR } \\
\left(\mathrm{W} \mathrm{m}^{-2} \text { year }^{-1}\right)\end{array}$ & 0.1739 & 0.0488 & 3.5616 & $>95$ & 0.4648 & 0.0463 & 10.0480 & $>95$ & 0.6432 & 0.0511 & 12.5980 & $>95$ \\
\hline $\begin{array}{l}\text { SW DIF } \\
\left(\mathrm{W} \mathrm{m}^{-2} \text { year }^{-1}\right)\end{array}$ & 0.4009 & 0.0489 & 8.2052 & $>95$ & -0.2204 & 0.0147 & 15.0360 & $>95$ & -0.3414 & 0.0214 & 15.9440 & $>95$ \\
\hline $\begin{array}{l}\text { SWC DIR } \\
\left(\mathrm{W} \mathrm{m}^{-2} \text { year }^{-1}\right)\end{array}$ & 0.0005 & 0.0331 & 0.0148 & $<90$ & -0.0758 & 0.0229 & 3.3132 & $>95$ & 0.0493 & 0.0061 & 8.0979 & $>95$ \\
\hline $\begin{array}{l}\text { SWC DIF } \\
\left(\mathrm{W} \mathrm{m}^{-2} \text { year }^{-1}\right)\end{array}$ & 0.4781 & 0.0253 & 18.8751 & $>95$ & 0.0906 & 0.0111 & 8.1834 & $>95$ & 0.0014 & 0.0022 & 0.6051 & $<90$ \\
\hline $\begin{array}{l}\text { AOD } \\
\text { (unitless) }\end{array}$ & 0.0009 & 0.0001 & 6.7010 & $>95$ & 0.0001 & 0.00005 & 1.1083 & $<90$ & & & & \\
\hline $\begin{array}{l}\text { Cloudiness } \\
\text { (unitless) }\end{array}$ & -0.0012 & 0.0004 & 2.7129 & $>95$ & -0.0031 & 0.0002 & 13.0811 & $>95$ & & & & \\
\hline
\end{tabular}

downwelling SW radiation from the direct into the diffuse field.

Next, the clear-sky direct and diffuse SW radiation from observations and model are examined; annual mean time series and trends over the CONUS domain are plotted in Figs. $8 \mathrm{c}-\mathrm{f}$ and $9 \mathrm{c}$ and d, respectively. If the "brightening" effect is primarily caused by the anthropogenic aerosol-direct effect, then in the absence of other forcing the clear-sky direct SW radiation should show an increasing trend while the clear-sky diffuse SW radiation would be expected to have a decreasing trend. However, in the observation, the clearsky direct SW radiation shows no trend (i.e., very small increasing) while the clear-sky diffuse SW radiation has an in- creasing trend. In the simulation, the aerosol-direct effects are clearly evident in the clear-sky direct and diffuse SW radiation (i.e., the results are the opposite of those in the observations, especially in the clear-sky diffuse radiation). Overall, the clear-sky SW radiation may be related at least in part to a decrease in aerosols, particularly in the eastern US where extensive reductions in the anthropogenic emissions of $\mathrm{SO}_{2}$ and $\mathrm{NO}_{x}$ resulted from the implementation of CAA. One of the indications that the aerosol-direct effect is contributing to "brightening" is shown in comparison of the FB case with the NFB case. Table 5 illustrates almost no trend in the no feedback case in clear-sky total, direct, and diffuse SW radiation. One of the indications that the aerosol-direct effect is con- 
Table 6. Statistics information (observation mean, correlation coefficient, $R$, mean bias, MB, normalized mean bias, NMB, root mean square different, RMSD, and normalized mean, NME, of model) for each network.

\begin{tabular}{lrrrrrr}
\hline & Obs. mean & $R$ & MB & NMB & RMSD & NME \\
\hline SURFRAD/ARM & & & & & & \\
\hline $\mathrm{SW}\left(\mathrm{W} \mathrm{m}^{-2}\right)$ & 182.85 & 0.948 & 22.46 & 12.28 & 23.79 & 12.68 \\
$\mathrm{SWC}\left(\mathrm{W} \mathrm{m}^{-2}\right)$ & 243.04 & 0.917 & -2.52 & -1.04 & 6.51 & 2.17 \\
$\mathrm{SW} \mathrm{DIR}\left(\mathrm{W} \mathrm{m}^{-2}\right)$ & 113.50 & 0.965 & 17.85 & 15.73 & 19.64 & 17.33 \\
$\mathrm{SW} \mathrm{DIF}\left(\mathrm{W} \mathrm{m}^{-2}\right)$ & 66.83 & 0.701 & 13.38 & 20.02 & 14.56 & 20.62 \\
$\mathrm{SWC}$ DIR $\left(\mathrm{W} \mathrm{m}^{-2}\right)$ & 207.90 & 0.812 & -9.17 & -4.41 & 14.42 & 5.14 \\
$\mathrm{SWC}$ DIF $\left(\mathrm{W} \mathrm{m}^{-2}\right)$ & 35.15 & 0.540 & 6.64 & 18.90 & 10.23 & 22.34 \\
$\mathrm{AOD}(\mathrm{unitless})$ & 0.12 & 0.795 & -0.06 & -51.77 & 0.07 & 51.42 \\
\hline $\mathrm{CASTNET}\left(\mu \mathrm{g} \mathrm{m}^{-3}\right)$ & & & & & & \\
\hline $\mathrm{SO}_{4}^{2-}$ & 2.64 & 0.967 & -0.47 & -17.88 & 0.65 & 19.91 \\
$\mathrm{SO}$ & & & & & & \\
$\mathrm{NO}_{3}^{-}$ & 2.10 & 0.946 & 0.17 & 5.34 & 1.10 & 31.61 \\
\hline $\mathrm{IMPROVE}^{-3}\left(\mu \mathrm{g} \mathrm{m}^{-3}\right)$ & & 0.933 & -1.06 & -46.12 & 1.17 & 54.40 \\
\hline $\mathrm{SO}_{4}^{2-}$ & 2.52 & 0.934 & -0.48 & -18.99 & 0.83 & 18.83 \\
$\mathrm{NO}_{3}^{-}$ & 0.90 & 0.933 & 0.24 & 26.94 & 0.53 & 49.63 \\
$\mathrm{EC}^{-3}$ & 2.49 & 0.872 & -1.07 & -42.95 & 1.23 & 48.21 \\
$\mathrm{PM}_{2.5}$ & 7.98 & 0.971 & 2.98 & 37.34 & 4.62 & 39.67 \\
\hline
\end{tabular}

Note: SW (all-sky shortwave radiation), SWC (clear-sky shortwave radiation), DIR (direct), DIF (diffuse), and AOD (aerosol optical depth).

tributing to the "brightening" is shown in comparison of the FB case with NFB case. As illustrated by the data tabulated in Table 5, almost no trends are apparent in the no feedback case for clear-sky total, direct, and diffuse SW radiation.

Nevertheless, as can be seen in Fig. 8b, the model trends in clear-sky total SW radiation agree in the aggregate with the eastern SURFRAD sites over the last 11 years (i.e., clear-sky SW 2000-2010 trends for obs_east: $0.3055 \mathrm{~W} \mathrm{~m}^{-2}$ year $^{-1}$, and sim_east: $0.1905 \mathrm{~W} \mathrm{~m}^{-2}$ year $\left.^{-1}\right)$. A similar result was found in the AOD 11 years (2000-2010) trend (obs_east: -0.0026 , sim_east: -0.0019$)$. One of the possible reasons for a better agreement over the latest 11 years is that the emissions data set may be more accurate for this more recent time period. For example, more detailed information (e.g., measurements provided by every state, point sources, and species) of emission sources and improved technology (e.g., new instruments for surface measurements) are available in later years for constructing the emissions data set which likely increased its accuracy.

Figure 8b illustrates that the 1995-2010 eastern SURFRAD trend is strongly influenced by two anomalous years (1998 and 1999). These anomalies are likely associated with the very strong El Niño occurrence of 1998-1999, which had significant impact on continental US weather patterns. For example, El Niño affects (i.e., increases) the US rain, snowfall, water vapor, and temperature in the atmosphere. As discussed in Long et al. (2009) and
Gan et al. (2014a), we allow for some amount of condensed water in the atmospheric column under the "clear sky" classification. Dupont et al. (2008) show that up to an optical depth of 0.15 , primarily elevated ice crystals are still typically classified as clear sky. Augustine and Dutton (2013) show, using SURFRAD data, that there exists a moderate correlation between ENSO (El Niño-Southern Oscillation), surface air temperature, and surface specific humidity at the SURFRAD sites. Their Fig. 7 shows the 1998-1999 El Niño increasing the yearly average specific humidity, with the Bondville and Goodwin Creek sites exhibiting the greatest increase of almost $1 \mathrm{~g} \mathrm{~kg}^{-1}$. This increased humidity likely also increased the occurrence and/or amount of condensed water in the atmospheric column at levels still classified as clear-sky, yet, as shown in their Fig. 8, also had an impact on the partitioning of the downwelling clear-sky SW radiation, significantly decreasing the downwelling direct SW radiation while increasing the diffuse SW radiation. In the west, the decreased direct SW anomaly is almost balanced by the increased diffuse SW radiation but not so for the east where the decrease in the direct SW radiation is much larger.

In contrast with the observed trends, the simulation with aerosol-direct feedback effect shows a clear association between decreasing aerosol burden with increasing clear-sky SW radiation and also better agreement with trends in observed total SW radiation. However, the comparison of the 
West

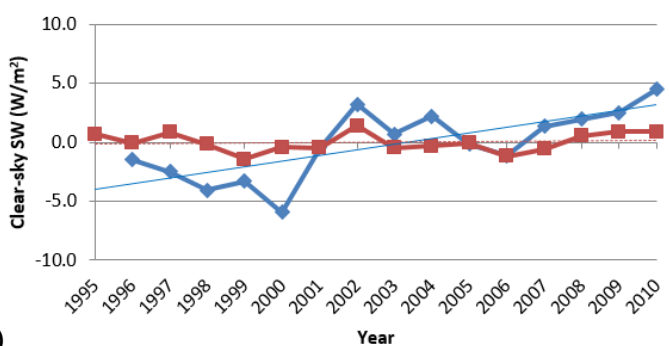

West

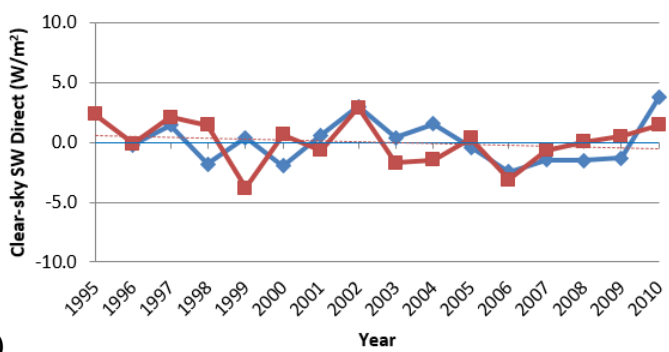

(c)

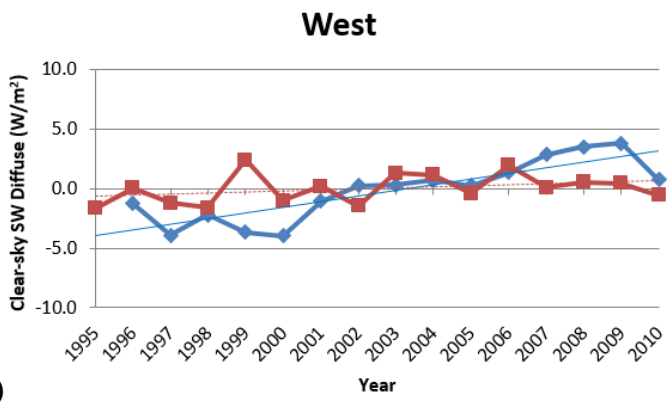

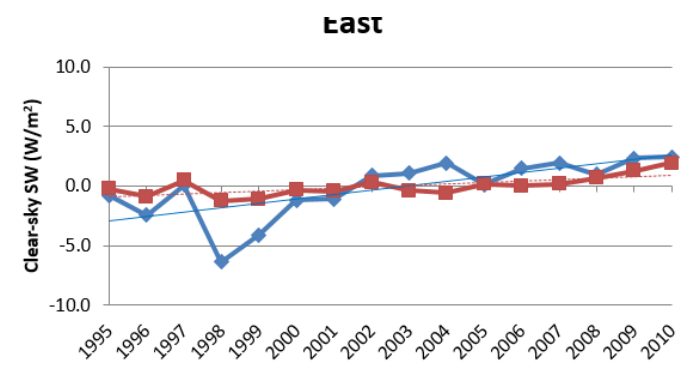

(b)

Yea

East

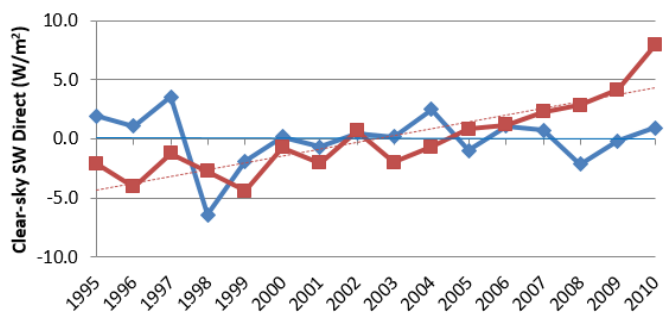

Year

East

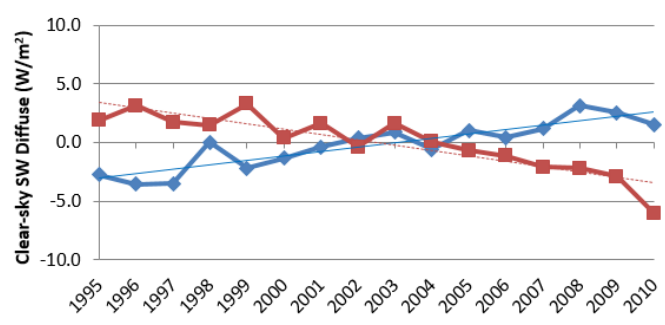

(f)

Figure 8. Annual mean anomalies of clear-sky total (top panels), direct (middle panels), and diffuse (bottom panels) SW radiation for the SURFRAD observations (blue line) and the modeled 16 years (red), together with their trends, respectively. The left column represents the western US, and the right column represents the eastern US.

clear-sky diffuse SW radiation in the feedback case with the observations shows that the radiative impacts of decreasing aerosol concentrations are confounded by other factors. As suggested by previous studies (Long et al., 2009; Augustine and Dutton, 2013; Gan et al., 2014a), some potential factors contributing to this discrepancy include increasing occurrences of contrail-generated ice haze that are caused by increasing air traffic producing an aggregate clear-sky "whitening" effect (a process missing in the current model), the traditional definition of "clear-sky" that allows for some small amount of condensed water in the column (Long et al., 2009, 2006; Dupont et al., 2008), and aerosol semi-direct and/or indirect effects (Ruckstuhl et al., 2008). For example, as a result of the increasing air traffic, ice haze layers associated with aircraft emission contrails (Hofmann et al., 1998) can potentially increase the diffuse radiation. More support for this theory was presented by Gan et al. (2014a); the pattern of US air carrier traffic (i.e., steady growth of air traffic from
1996 to 2007 , followed by a decrease after 2008) agreed well with the pattern inferred in the observed clear-sky diffuse radiation especially during the last 3 years (i.e., both patterns decreased). Moreover, Haywood et al. (2009) and Gerritsen (2012) illustrated that increasing contrails do increase the diffuse radiation. This suggests that contrails or subvisual cirrus clouds and ice haze can play a role in the increasing trend noted in the observed clear-sky diffuse SW radiation. To capture this, a realistic characterization of air traffic emission and the optical properties of the contrails (e.g., crystal shapes, ice layers, and altitude) in the model is needed and will be pursued as part of a future study. Additionally, the water vapor concentration (Haywood et al., 2011) can possibly impact the surface radiation. Thus, further investigation is needed to quantify and attribute the causes of the increase of measured clear-sky diffuse SW radiation. 
(a)

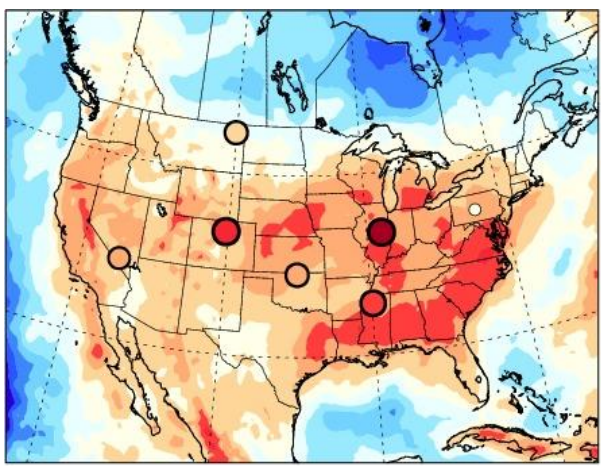

Min: -1.31 Max: .959

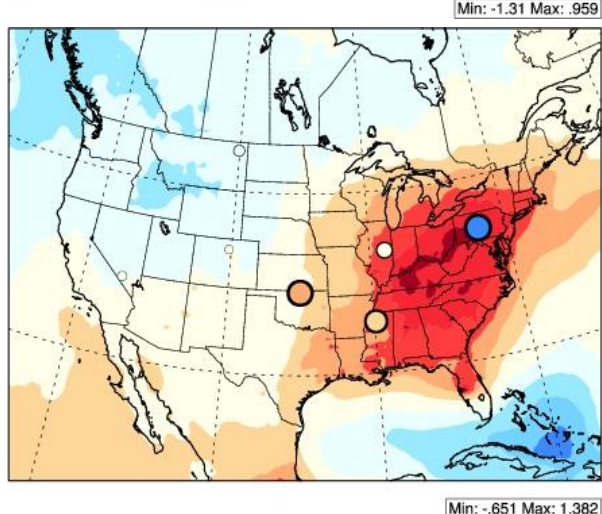

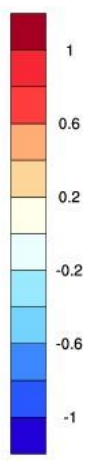

(b)

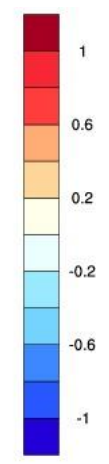

(d)

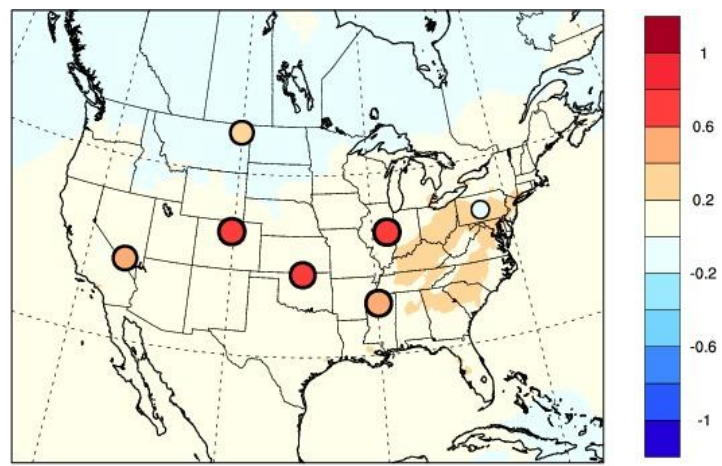

Min: -.2118 Max: 3094

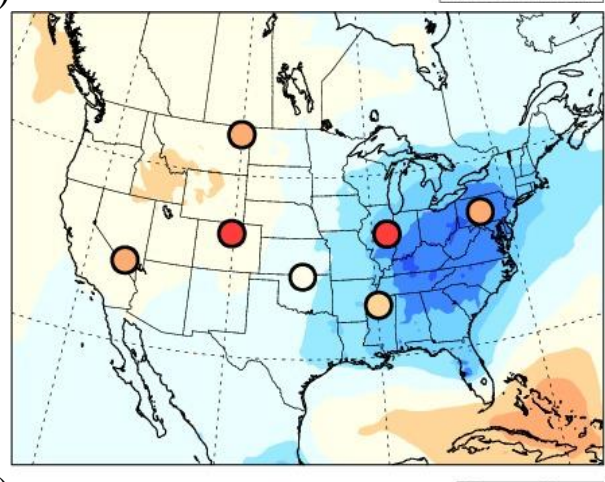

Min: - -1.075 Max: .59

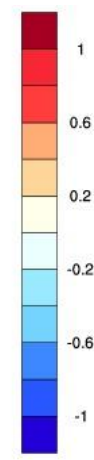

Figure 9. Map of annual trends based on 1995-2010 coupled WRF-CMAQ simulations over the CONUS domain for (a) all-sky total SW radiation, (b) clear-sky total SW radiation, (c) clear-sky direct SW radiation, and (d) clear-sky diffuse SW radiation depicted along with circles representing SURFRAD-observed trends for seven sites. Note that the size of the circle represents the level of the significance. A larger circle indicates more significance.

\section{Summary and conclusions}

In general, the coupled WRF-CMAQ model is capable of replicating the observed trends in surface particulate matter concentration and AOD even though the magnitude of observed AOD is underestimated by the model. Possible causes of this underestimation could be underrepresentation of some particulate matter constituent species in the model such as sea salt, organic carbon and other hygroscopic properties in the aerosol optics calculations, and uncertainties in the representation of the mixing state (Gan et al., 2014b; Curci et al., 2015).

The analysis of modeled and observed clear-sky total SW trends shows they are more consistent with each other during 2000-2010 than those during 1995-2010, suggesting that the improved agreement for the more recent period may be due to better emission estimates. For example, wildfire emissions are provided by states after 2002 instead of national totals. As mentioned in Xing et al. (2013), for earlier years, information for some sectors was not as detailed as recent data, so scaling factors based on activities were used to estimate some of the earlier years' emission sources. This finding illustrates the importance of the accurate specification of the changes in emissions for capturing the changes in aerosol burden and their radiative effects. Shortwave "brightening" trends are apparent in both observations and model calculations for the past 16 years, though the magnitude is underestimated in the model. One reason for using the modeling is to fill in for the lack of spatial coverage of the observations, which in turn can help us to better understand the overall aerosol-direct effects in the US.

Our analysis suggests an association between the SW radiation "brightening" (both all-sky and clear-sky) and troposphere aerosol burden over the past 16 years especially in the eastern US, where large reductions in airborne particulate matter have occurred. Even though the "brightening" effect is underestimated in the clear-sky SW radiation in the model, it is still able to capture the total SW trend derived from the observations (i.e., both observations and model predictions illustrate increasing trends but smaller magnitude in the model), especially for the more recent years. As a consequence of the CAA controls, a dramatic reduction in particulate matter concentrations, especially $\mathrm{SO}_{4}^{2-}$ and $\mathrm{NO}_{3}^{-}$, is found in the eastern US.

Radiation trends in the western US could be influenced by local terrain (Oliphant et al., 2003; Wen et al., 2009) influences as well as episodic long-range pollution transport, which may contribute to the lack of a clear relationship be- 
tween trends in aerosol burden and surface radiation at these locations. As stated by Gan et al. (2014a), the long-range transport of aerosol/dust plumes can cause enhancements in both surface aerosol concentrations and AOD (Gan et al., 2008; Mathur, 2008; Miller et al., 2011; Uno et al., 2011) and possibly contribute to the noted trends of tropospheric aerosol burden both at the surface and aloft.

Trends of observed and simulated clear-sky diffuse SW radiation show opposite signs. Potential contributors to this discrepancy include increasing ice deposition in the upper atmosphere from growing air traffic that is not considered in the model, differences in the classification of "clear-sky" conditions between the radiation retrieval methodology and the model, differences in simulated cloudiness, and aerosol semi-direct and indirect effects not represented in the current model simulations. In general, the representation of the trends in clear-sky and all-sky SW radiation in the simulation with aerosol-direct effects relative to the observation are captured much better compared to the simulation without these effects. This indicates that at least some of the trends in the recent radiation brightening, especially in the eastern US, are likely influenced by decreasing aerosol levels in the region, which in turn have resulted from the control of emissions of anthropogenic particulate matter and precursor species.

Acknowledgements. This research was performed while ChuenMeei Gan held a National Research Council Research Associateship Award at the US EPA. The research presented in this study was supported through an interagency agreement between the US Department of Energy (funding IA DE-SC0003782) and the US Environmental Protection Agency (funding IA RW-89-9233260). It has been subject to the US EPA's administrative review and approved for publication. The authors also would like thank John Augustine from NOAA-SURFRAD for his support and assistance in obtaining the SURFRAD data, as well as the NOAA Earth System Research Laboratory (ESRL) Global Monitoring Division (GMD) for their diligent efforts in operating and maintaining the SURFRAD sites. C. N. Long acknowledges the support of the Climate Change Research Division of the US Department of Energy as part of the Atmospheric Radiation Measurement (ARM) and Atmospheric System Research (ASR) programs, and the support of the Cooperative Institute for Research in Environmental Sciences (CIRES). The authors would like thank James Kelly from the US EPA for his comments.

Edited by: J. Quaas

\section{References}

Appel, K. W., Pouliot, G. A., Simon, H., Sarwar, G., Pye, H. O. T., Napelenok, S. L., Akhtar, F., and Roselle, S. J.: Evaluation of dust and trace metal estimates from the Community Multiscale Air Quality (CMAQ) model version 5.0, Geosci. Model Dev., 6, 883-899, doi:10.5194/gmd-6-883-2013, 2013.

Augustine, J. A. and Dutton, E. G.: Variability of the surface radiation budget over the United States from 1996 through 2011 from high-quality measurements, J. Geophys. Res. Atmos., 118, 43-53, doi:10.1029/2012JD018551, 2013.

Blanchard, C. L., Hidy, G. M., Tanenbaum, S., Edgerton, E. S., and Hartsell, B. E.: The Southeastern Aerosol Research and Characterization (SEARCH) study: Temporal trends in gas and PM concentrations and composition, 1999-2010, JAPCA J. Air Waste Ma., 63, 247-259, 2013.

Carlton, A. G., Bhave, P., Napelenok, S., Edney, E. O., Sarwar, G., Pinder, R. W., Pouliot, G., and Houyoux, M.: Model Representation of Secondary Organic Aerosol in CMAQ v4.7, Environ. Sci. Technol., American Chemical Society, Washington, DC, 44, 8553-8560, 2010.

Chin, M., Diehl, T., Tan, Q., Prospero, J. M., Kahn, R. A., Remer, L. A., Yu, H., Sayer, A. M., Bian, H., Geogdzhayev, I. V., Holben, B. N., Howell, S. G., Huebert, B. J., Hsu, N. C., Kim, D., Kucsera, T. L., Levy, R. C., Mishchenko, M. I., Pan, X., Quinn, P. K., Schuster, G. L., Streets, D. G., Strode, S. A., Torres, O., and Zhao, X.-P.: Multi-decadal aerosol variations from 1980 to 2009: a perspective from observations and a global model, Atmos. Chem. Phys., 14, 3657-3690, doi:10.5194/acp-14-3657-2014, 2014.

Curci, G., Hogrefe, C. Bianconi, R., Im, U., Balzarini, A., Baró, R., Brunner, D., Forkel, R., Giordano, L., Hirtl, M., Honzak, L., Jiménez-Guerrero, P., Knote, C., Langer, M., Makar, P.A., Pirovano, G., Pérez, J.L., San José, R., Syrakov, D., Tuccella, P., Werhahn, J., Wolke, R., Žabkar, R., Zhang, J., and Galmarini, S.: Uncertainties of simulated aerosol optical properties induced by assumptions on aerosol physical and chemical properties: An AQMEII-2 perspective, Atmos. Environ., 115, 541552, doi:10.1016/j.atmosenv.2014.09.009, 2015.

Dupont, J. C., Haeffelin, M., and Long C. N.: Evaluation of cloudless-sky periods detected by shortwave and longwave algorithms using lidar measurements, Geophys. Res. Lett., 35, L10815, doi:10.1029/2008GL033658, 2008.

Foley, K. M., Roselle, S. J., Appel, K. W., Bhave, P. V., Pleim, J. E., Otte, T. L., Mathur, R., Sarwar, G., Young, J. O., Gilliam, R. C., Nolte, C. G., Kelly, J. T., Gilliland, A. B., and Bash, J. O.: Incremental testing of the Community Multiscale Air Quality (CMAQ) modeling system version 4.7, Geosci. Model Dev., 3, 205-226, doi:10.5194/gmd-3-205-2010, 2010.

Gan, C. M., Gross, B., Moshary, F., and Ahmed, S.: Analysis of the Interaction of Aerosol Transport Layers on Local Air Quality, Geoscience and Remote Sensing Symposium, 7-11 July 2008, Boston, MA, USA, IGARSS, 307-310, doi:10.1109/IGARSS.2008.4779719, 2008.

Gan, C.-M., Pleim, J., Mathur, R., Hogrefe, C., Long, C. N., Xing, J., Roselle, S., and Wei, C.: Assessment of the effect of air pollution controls on trends in shortwave radiation over the United States from 1995 through 2010 from multiple observation networks, Atmos. Chem. Phys., 14, 1701-1715, doi:10.5194/acp14-1701-2014, 2014a. 
Gan, C.-M., Binkowski, F., Pleim, J., Xing, J., Wong, D., Mathur, R., and Gilliam, R.: Assessment of the Aerosol Optics Component of the Coupled WRF-CMAQ Model using CARES Field Campaign data and a Single Column Model, Atmospheric Environment, Atmos. Environ., 115, 670-682, doi:10.1016/j.atmosenv.2014.11.028, 2014b.

Gerritsen, K. O.: Case study on the effect of aircraft induced cloudiness on the shortwave solar irradiance at the land surface, Internship report of Earth System Science (ESS-70433), Royal Netherlands Meteorological Institute, Ministry of infrastructure and the Environment, http://bibliotheek.knmi.nl/stageverslagen/ traineereport_Gerritsen.pdf (last access: 30 October 2015), June 2012.

Hand, J. L., Schichtel, B. A., Malm, W. C., and Pitchford, M. L.: Particulate sulfate ion concentration and $\mathrm{SO}_{2}$ emission trends in the United States from the early 1990s through 2010, Atmos. Chem. Phys., 12, 10353-10365, doi:10.5194/acp-1210353-2012, 2012.

Hand, J. L., Schichtel, B. A., Malm, W. C., and Frank, N. H.: Spatial and temporal trends in $\mathrm{PM}_{2.5}$ organic and elemental carbon across the United States, Advances in Meteorology, 2013, 367674, doi:10.1155/2013/367674, 2013.

Haywood, J. M., Allan, R. P., Bornemann, J., Forster, P. M., Francis, P. N., Milton, S., Rädel, G., Rap, A., Shine, K. P., and Thorpe, G.: A case study of the radiative forcing of persistent contrails evolving into contrail-induced cirrus, J. Geophys. Res., 114, D24201, doi:10.1029/2009JD012650, 2009.

Haywood, J. M., Bellouin, N., Jones, A., Boucher, O., Wild, M., and Shine, K. P.: The roles of aerosol, water vapor and cloud in future global dimming/brightening, J. Geophys. Res. 116, D20203, doi:10.1029/2011JD016000, 2011.

Hofmann, D. J., Stone, R., Wood, M. E., Deshler, T., and Harris, J. M.: An analysis of 25 years of balloon borne aerosol data in search of a signature of the subsonic commercial aircraft fleet, Geophys. Res. Lett., 25, 2433-2436, 1998.

Hogrefe, C., Pouliot, G., Wong, D., Torian, A., Roselle, S., Pleim, J., and Mathur, R.: Annual Application and Evaluation of the Online Coupled WRF-CMAQ System over North America under AQMEII Phase 2, Atmos. Environ., 115, 683-694, doi:10.1016/j.atmosenv.2014.12.034, 2015.

IPCC: Climate Change 2014: Impacts, Adaptation, and Vulnerability. Part A: Global and Sectoral Aspects. Contribution of Working Group II to the Fifth Assessment Report of the Intergovernmental Panel on Climate Change, edited by: Field, C. B., Barros, V. R., Dokken, D. J., Mach, K. J., Mastrandrea, M. D., Bilir, T. E., Chatterjee, M., Ebi, K. L., Estrada, Y. O., Genova, R. C., Girma, B., Kissel, E. S., Levy, A. N., MacCracken, S., Mastrandrea, P. R., and White, L. L., Cambridge University Press, Cambridge, UK and New York, NY, USA, 1132 pp., 2014a.

IPCC: Climate Change 2014: Impacts, Adaptation, and Vulnerability. Part B: Regional Aspects. Contribution of Working Group II to the Fifth Assessment Report of the Intergovernmental Panel on Climate Change, edited by: Barros, V. R., Field, C. B., Dokken, D. J., Mastrandrea, M. D., Mach, K. J., Bilir, T. E., Chatterjee, M., Ebi, K. L., Estrada, Y. O., Genova, R. C., Girma, B., Kissel, E. S., Levy, A. N., MacCracken, S., Mastrandrea, P. R., and White, L. L., Cambridge University Press, Cambridge, UK and New York, NY, USA, 688 pp., 2014 b.
Long, C. N., Sabburg, J. M., Calbo, J., and Page, D.: Retrieving Cloud Characteristics from Ground-based Daytime Color Allsky Images, J. Atmos. Ocean. Tech., 23, 633-652, 2006.

Long, C. N., Dutton, E. G., Augustine, J. A., Wiscombe, W., Wild, M., McFarlane, S. A., and Flynn, C. J.: Significant decadal brightening of downwelling shortwave in the continental United States, J. Geophys. Res., 114, D00D06, doi:10.1029/2008JD011263, 2009.

Mathur, R.: Estimating the impact of the 2004 Alaskan forest fires on episodic particulate matter pollution over the eastern United States through assimilation of satellite derived aerosol optical depths in a regional air quality model, J. Geophys. Res., 113, D17302, doi:10.1029/2007JD009767, 2008.

Miller, D. J., Sun, K., Zondlo, M. A., Kanter, D., Dubovik, O., Welton, E. J., Winker, D. M., and Ginoux, P.: Assessing boreal forest fire smoke aerosol impacts on US air quality: A case study using multiple data sets, J. Geophys. Res.,116, D22209, doi:10.1029/2011JD016170, 2011.

Oliphant, A. J., Spronken-Smith, R. A., Sturman, A. P., and Owens, I. F.: Spatial Variability of Surface Radiation Fluxes in Mountainous Terrain, J. Appl. Meteor., 42, 113-128. doi:10.1175/15200450(2003)042<0113:SVOSRF>2.0.CO;2, 2003.

Pleim, J. E.: A combined local and nonlocal closure model for the atmospheric boundary layer. Part II: Application and evaluation in a mesoscale meteorological model, J. Appl. Meteorol. Clim., 46, 1396-1409, 2007.

Pleim J. E. and Gilliam, R.: An indirect data assimilation scheme for deep soil temperature in the Pleim-Xiu land surface model, J. Appl. Meteor. Clim., 48, 1362-1376, 2009.

Pleim, J. E. and Xiu, A.: Development of a land surface model. Part II: Data Assimilation, J. Appl. Meteor., 42, 1811-1822, 2003.

Ruckstuhl, C., Philipona, R., Behrens, K., Coen, C. M., Durr, B., Heimo, A. Matzler, C., Nyeki, S., Ohmura, A., Vuilleumier, L., Weller, M., Wehrli, C., and Zelenka, A.: Aerosol and cloud effects on solar brightening and the recent rapid warming, Geophys. Res. Lett., 35, L12708, doi:10.1029/2008GL034228, 2008.

Stauffer, R. D. and Seaman, L. N.: Multiscale FourDimensional Data Assimilation, J. Appl. Meteor., 33, 416-434, doi:10.1175/1520-0450(1994)033<0416:MFDDA>2.0.CO;2, 1994.

Uno, I., Eguchi, K., Yumimoto, K., Liu, Z., Hara, Y., Sugimoto, N., Shimizu, A., and Takemura, T.: Large Asian dust layers continuously reached North America in April 2010, Atmos. Chem. Phys., 11, 7333-7341, doi:10.5194/acp-11-7333-2011, 2011.

Wang, J., Wang, S., Jiang, J., Ding, A., Zheng, M., Zhao, B., Wong, D., Zhou, W., Zheng, G., Wang, L., Pleim, J., and Hao, J.: Impact of aerosol-meteorology interactions on fine particle pollution during China's severe haze episode in January 2013, Environ. Res. Lett., 9, 094002, doi:10.1088/1748-9326/9/9/094002, 2014.

Weatherhead, E. C., Reinsel, G. C., Tiao, G. C., Meng, X.-L., Choi, D., Cheang, W.-K., Keller, T., DeLuisi, J., Wuebbles, D. J., Kerr, J. B., Miller, A. J., Oltmans, S. J., and Frederick, J. E.: Factors affecting the detection of trends: Statistical considerations and applications to environmental data, J. Geophys. Res., 103, 1714917161, doi:10.1029/98JD00995, 1998.

Wen, J., Liu, Q., Liu, Q., Xiao, Q., and Li, X.: Scale effect and scale correction of land-surface albedo in rugged terrain, Int. J. Remote Sens., 30, 5397-5420, 2009. 
Wild, M., Trüssel, B., Ohmura, A., Long, C. N., König-Langlo, G., Dutton, E. G., and Tsvetkov, A.: Global dimming and brightening: An update beyond 2000, J. Geophys. Res., 114, D00D13, doi:10.1029/2008JD011382, 2009.

Wong, D. C., Pleim, J., Mathur, R., Binkowski, F., Otte, T., Gilliam, R., Pouliot, G., Xiu, A., Young, J. O., and Kang, D.: WRFCMAQ two-way coupled system with aerosol feedback: software development and preliminary results, Geosci. Model Dev., 5, 299-312, doi:10.5194/gmd-5-299-2012, 2012.

Xing, J., Pleim, J., Mathur, R., Pouliot, G., Hogrefe, C., Gan, C.-M., and Wei, C.: Historical gaseous and primary aerosol emissions in the United States from 1990 to 2010, Atmos. Chem. Phys., 13, 7531-7549, doi:10.5194/acp-13-7531-2013, 2013.
Xing, J., Mathur, R., Pleim, J., Hogrefe, C., Gan, C.-M., Wong, D. C., Wei, C., Gilliam, R., and Pouliot, G.: Observations and modeling of air quality trends over 1990-2010 across the Northern Hemisphere: China, the United States and Europe, Atmos. Chem. Phys., 15, 2723-2747, doi:10.5194/acp-15-2723-2015, 2015.

Yu, S., Mathur, R., Pleim, J., Wong, D., Gilliam, R., Alapaty, K., Zhao, C., and Liu, X.: Aerosol indirect effect on the grid-scale clouds in the two-way coupled WRF-CMAQ: model description, development, evaluation and regional analysis, Atmos. Chem. Phys., 14, 11247-11285, doi:10.5194/acp-14-11247-2014, 2014. 